\title{
An Aria by František Škroup for Halévy's opera La Juive
}

\section{Milan Pospísil}

Abstract: At the Czech Museum of Music there is a manuscript of an aria composed by František Škroup as an insertion for Halévy's opera La Juive. As the conductor of the Estates Theatre, Škroup wrote it for the first German-language performance of the opera in Prague in 1838. The aria was inserted into the role of Eudoxie/Isabella so the singer of the part, Katharina Podhorsky, would get to present herself as a soloist, having been denied that opportunity by the cuts in the printed score of Halévy's opera. The aria was suitably placed at the beginning of Act IV, but the German text by an unknown author departs from the drama's sequence of cause and effect found Scribe's libretto. The insertion takes the form of a two-part aria (Cantabile - Cabaletta) of the kind used for large vocal numbers in emotionally intense situations. The composition conforms to the practice at that time of inserting arias by different composers into operas, and Podhorsky also engaged in this practice. The coloratura writing at the conclusion of the aria was apparently intended to feature her strengths as a singer.

Key words: La Juive, Fromental Halévy, Eugène Scribe, František Škroup, Katharina Podhorsky, Giacomo Meyerbeer, Eduard Hanslick, opera, aria, music criticism, Estates Theatre, Prague, Czech music, first half of the $19^{\text {th }}$ century

\section{Source}

In the collection of the Music History Department of the Czech Museum of Music (hereinafter NM-CMH) under shelf mark XIX E 60 there is a musical manuscript with the following heading on the title page:

Einlags=Arie || zu der Oper || Die Jüdinn || componirt von || F. Skraup. || Kapellmeister am k. st. Theater zu Prag. || [text crossed out in ink to the point of illegibility] || Prag, am 23 July 1838

Glued to the upper left corner of the title page is a rectangular, printed label that reads Museum Regni Bohemiae with the Bohemian lion on the coat-of-arms and with a crown. A label bears the shelf mark XIX E 60 written in ink. At the bottom in the middle is a round, red rubberstamp impression that reads Museum Regni Bohemiae and bears a Bohemian lion. A pencil inscription on the bottom right reads: Darovala [Donated by] Bož. Škroupová 1921.

The manuscript consists of two sewn signatures of strongly green-tinted paper in a horizontal format with 16 staves. The first signature, $258 \times 333 \mathrm{~mm}$, consists of six sheets

This study is the result of research activity supported by the Grant Agency of the Czech Republic, project registration number 20-19382S. I wish to thank Jiř́ K. Kroupa, Wolfgang Kühnhold, Jitka Ludvová, Aneta Peterová, Vlasta Reittererová, and Hartmut Schick for their collegial assistance with the creation of this article. 
(12 folios, 24 pp.), and the second signature, $260 \times 330 \mathrm{~mm}$, consists of five 5 sheets $(9$ folios; the right half of the fifth sheet has been trimmed off, 18 pp.), for a total of 21 folios and 42 pages. The paper of the first and last page is yellowed and soiled, and liquid has been spilled on the last page. The outer edges of the pages are partially warped in the shape of the arc of a circle, and they worn at the corners.

On all of the pages, there is writing in brown-black ink. The musical text (score) is a manuscript by František Škroup, and the calligraphic writing of the text is apparently in a different hand. There are also changes to the text and notes made in ink and pencil in Škroup's hand, and conductors' comments in pencil are visible as well.

The page numbers in pencil in the bottom margin in the middle and on the interior and exterior margins are erroneous. The number 42 is written on the last page in the upper left corner in pencil.

\section{Purpose of the composition}

Škroup's aria has been known to exist. Josef Plavec mentions it in his monograph about

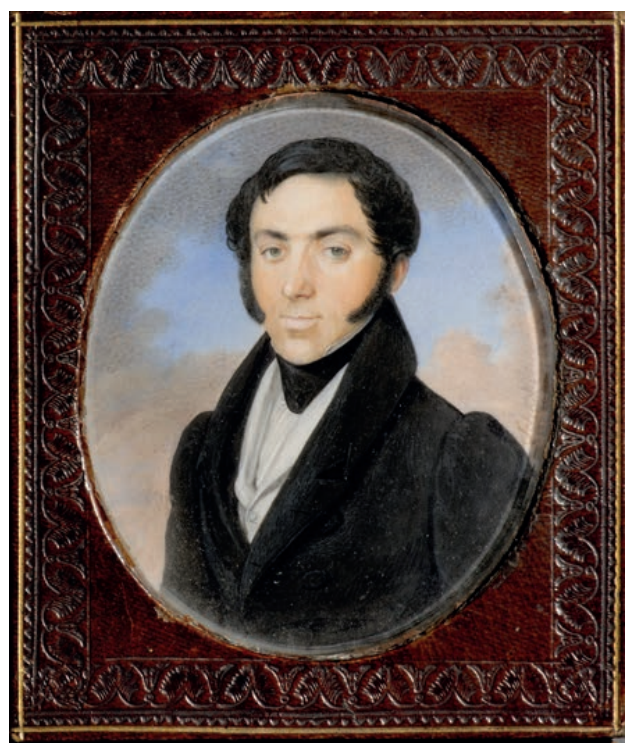

František Škroup (1801-1862)

By Heinrich Schödl, Prague, ca. 1825-1830 / Autor Heinrich Schödl, Praha, asi 1825-1830

Miniature painting, watercolour and gouache paint on an ivory plate, glazed, in the original leather case with flaps, signed "Schödl."I

Miniatura malovaná akvarelem a kvašem na slonovinové destičce, zasklená v původní kožené etuji s chlopněmi, sign. „Schödl."

National Museum / Národní muzeum, inv. no. / inv. č. H2-14 787

(c) Jan Rendek

Škroup, but no attention has been paid to it since then. ${ }^{1}$ In the $19^{\text {th }}$ century, the insertion of arias from other operas and the composing of alternative arias for one's own operas or for those of others was routine practice in theatres. As a conductor at the Estates Theatre, Śkroup supplied music for performances of a number of theatrical works in various genres ranging from individual numbers to complete incidental music, ${ }^{2}$ but in his now known oeuvre, this is a unique instance of him composing an inserted aria. It was apparently connected with the first Prague performances of Fromental Halévy's opera La Juive (The Jewess). Škroup's production in German used the title Die Jüdinn and was based on a version approved by the Austrian censors that was prepared by Joseph Ritter von Seyfried and Georg Edler von Hofmann.

1) See PLAVEC, Josef: František Škroup, Melantrich, Praha 1940, pp. 333-334.

2) For information about Škroup's compositions for the theatre, see KABELKOVÁ, Markéta - LUDVOVÁ, Jitka: Škroup, František Jan [entry], in: LUDVOVÁ, Jitka et col.: Hudební divadlo v českých zemích (Music Theatre in the Czech Lands), Divadelní ústav - Academia, Praha 2006, pp. 536-542 (hereinafter LUDVOVÁ 2006), and in: Česká divadelní encyklopedie [online]. Retrieved from: http://encyklopedie.idu.cz/index. php/\%C5\%AOkroup,_Franti\%C5\%Alek_Jan [accessed on 6 Feb. 2021]. 
The premiere took place on 25 July 1838. ${ }^{3}$ The aria belongs to the role of Eudoxie (Isabella in the censored version), so it was intended for the singer of the role, Kateřina Podhorská. ${ }^{4}$ For Podhorská as the leading singer of the Prague opera company, performing in new works of French grand opéra was a matter of course and a question of prestige. This can also be seen from the fact that she was performing excerpts from the operas on the concert stage even in advance of their theatrical premieres in Prague. On 12 March 1838, a few months before the first performance, she sang the Act IV duet of Eudoxie and Rachel (Sara in the censored version) from Halévy’s opera with Henrietta Grosserová.

"The ladies Grosserová and Podhorská performed the duet from Halévy's 'The Jewess' with distinction, although it is little suited to the concert hall."

"Miss Grosserová and Mrs. Podhorská sang very skilfully in the duet from 'The Jewess', an opera that is still unknown to Prague audiences."5

At the same concert, Podhorska sang the part of Marguerite in the big seventh scene from Act II of Meyerbeer's opera Les Huguenots, which was not performed at the Estates Theatre until 1840 in a censored version as Die Ghibellinen in Pisa.

"[...] A vocal number from 'The Huguenots' by Meyerbeer was performed (for the first time) by Mrs. Podhorská, Mrs. Schumannová, Miss Balzerová, Siegfried Rosenberg, and sopranos from the new Jewish synagogue; it is unquestionably one of the most difficult vocal numbers ever written, but although Mrs. Podhorská, who sang the solo part, put forth all of her artistry, the success was still not commensurate with the performance. Both this solo number with

3) Concerning theatrical censorship in Austria and the Czech lands, see BACHLEITNER, Norbert: Die literarische Zensur in Österreich von 1751 bis 1848, Böhlau Verlag, Wien - Köln - Weimar 2017 (Literaturgeschichte in Studien und Quellen, Bd. 28) (hereinafter BACHLEITNER); SCHERL, Adolf: $K$ nejstarším dějinám divadelní cenzury v Čechách (On the Oldest History of Theatre Censorship in Bohemia), Divadelní revue, vol. 25, 2014, no. 1, pp. 7-18; PÍŠA, Petr: Cenzura v Čechách v kontextu předbřeznové habsburské monarchie (Censorship in Bohemia in the context of the Habsburg Monarchy in the Vormärz period), dissertation, Univerzita Karlova Filozofická fakulta - Ústav českých dějin, [Praha] 2018. - For more about the censored form of the opera La Juive in Vienna and in Prague, see HEIDLBERGER, Franz: Halévys Jüdin in Wien. Zur Rezeptionsgeschichte einer Oper zwischen Zensur und Antisemitismus, in: Actes du colloque Fromental Halévy, eds. F. Claudon - G. de Van - K. Leich-Galland, Paris, Novembre 2000 (Etudes sur l’opéra français du XIXe siècle, vol. V), Musik-Edition Lucie Galland, Weinsberg 2003, pp. 244-266 (hereinafter CLAUDON), and POSPÍŠIL, Milan: Österreichische Opernzensur in Prag: Gustave III und La Juive, in: Eugène Scribe und das europäische Musiktheater (Forum Musiktheater, Bd. 6), ed. Sebastian Werr, LIT Verlag, Berlin 2007, pp. 122-152.

4) The singer Kateřina Podhorská, nee Kometová (1807-1889), was one of the best and most popular Prague opera performers. See LUDVOVÁ, Jitka: Podhorská, Kateřina [entry], in: LUDVOVÁ 2006, op. cit. in footnote no. 2, pp. 408-411, and in: Česká divadelní encyklopedie [online]. Retrieved from: http://encyklopedie.idu.cz/index.php/ Podhorsk\%C3\%Al,_Kate\%C5\%99ina [accessed on 26 Feb. 2021]; Katharina Comet [entry], in: Carl-Maria-vonWeber-Gesamtausgabe. Digitale Edition [online]. Retrieved from: http://weber-gesamtausgabe.de/A000B8D [accessed on 26 Feb. 2021]; Katharina Podhorský (geb. Comet) [entry], in: Oesterreichisches Musiklexikon [online]. Retrieved from: https://www.musiklexikon.ac.at/ml?frames=no [accessed on 26 Feb. 2021].

5) "Ein Duett aus der ,Jüdin' von Halevy trugen die Damen Großer und Podhorsky mit Auszeichnung vor, obschon es sich wenig für den Concertsaal eignet.” B.: Concert vom 5. März, Bohemia, vol. 11, 1838, no. 32 (16 March), p. [3]; "Dem. Großer und Mad. Podhorsky sangen recht wacker ein Duett ans der ,Jüdin', welche Oper den Pragern noch unbekannt ist.” Dr. A.: Am 12. März fand in Prag [...], Allgemeine Theaterzeitung und Originalblatt für Kunst, Literatur, Musik und geselliges Leben, vol. 31, 1838, no. 67 (3 April), p. 296. 
three accompanying voices and the duet from the opera 'The Jewess' by Halevy (for the first time), performed by Miss Grosserová and Mrs. Podhorská again showed us that arias and duets whether from French or the latest German music are not suitable for a concert."

Podhorská sang the aria of Marguerite again at a concert presented by the violinist August Pott $^{7}$ at the Estates Theatre on 26 September 1838:

"At the concert, Mrs. Podhorská performed a brilliant aria by Meyerbeer so superbly that the public rewarded her with an ovation equal to that which the featured artist of the concert had received."

Halévy employed voice types for the main female roles in a constellation similar to what Meyerbeer had done before him in the opera Robert le diable. The roles of Alice and Isabella are written for singers of the first rank who, as Eduard Hanslick described it, were expected to combine "brilliant vocal technique with emotional interpretation of recitatives and passionate expression for powerfully moving situations", although in them one sees the beginning of the later division of soprano roles into "dramatic" and "coloratura" types. "Meyerbeer divides prima donnas into those who have mastery of virtuosic coloratura singing and those who lack it. Verdi and especially Richard Wagner know singers of only one kind: 'dramatic', i.e. those who are incapable of coloratura singing and by the grace of the maestro have no need of it.. Nonetheless, with Meyerbeer such a division of labour is not unconditional. This is documented by, among other things, the repertoire of female singers at the Académie royale de musique in Paris. At the premiere of the opera Robert le diable (1831), Julie Dorus-Gras sang the part of Alice, a dramatic role,$^{10}$ and Laura Cinti-Damoreau sang the coloratura part of Isabella. ${ }^{11}$

6) "[...] Ein Gesangstück aus den ,Hugenotten' von Meyerbeer (zum erstenmal), vorgetragen von Mad. Podhorsky, Mad. Schumann, Dem. Balzer und Siegfried Rosenberg, Sopranisten an dem neuen israel. Bethause, gehört unstreitig unter die schwierigsten Gesangsnummern, die je geschrieben wurden; aber wenn gleich Mad. Podhorsky, welche die Solostimme übernommen hatte, ihre ganze Kunst aufbot, so war doch der Erfolg nicht in Uebereinstimmung mit der Leistung, und sowohl dieser dreistimmig begleitete Sologesang, als das Duett aus der Oper ,Die Jüdin' von Halévy (zum erstenmal), vorgetragen von Dem. Grosser und Mad. Podhorsky, thaten aufs Neue die Wahrheit kund, dass die Arien und Duetten weder der französischen noch der neuern deutschen Musik sich für das Concert eignen." Nachrichten. Prag. (Schluss.), Allgemeine musikalische Zeitung, vol. 40, 1838, no. 16 (18 April), p. 258.

7) August Pott (1806-1883) was a German violinist and composer.

8) "Mad. Podhorsky trug bei diesem Concerte eine brillante Arie von Meyerbeer so ausgezeichnet vor, daß sie das Publikum mit demselben Beifalle, welcher dem Concertgeber zu Theil wurde, hervorrief." MÜLLER, Anton: Kunst und Leben in Böhmen. Theaterbericht vom 19. bis 26. September, Bohemia, vol. 11, 1838, no. 116 (28 Sept.), p. [4].

9) "[...] [eine Sängerin, welche] eine brillante Gesangstechnik mit pathetischem Vortrag des Recitativs und leidenschaftlichem Ausdruck starker bewegter Situationen vereinigte [...] Meyerbeer theilt die Primadonnen schon in solche, welche Virtuosität im colorirten Gesang besitzen, und solche, denen sie fehlt. Verdi und vollends Richard Wagner kennen nur mehre Eine Gattung Sängerinnen: ,dramatische', das heißt solche, die des colorirten Gesanges nicht mächtig sind und dessen von Maestros Gnaden auch nicht bedürfen." HANSLICK, Eduard: Mozart, in: HANSLICK, Eduard: Die moderne Oper. Kritiken und Studien, A. Hofmann \& Co., Berlin 1875, pp. 29-60, here p. 53.

10) Julie Dorus-Gras (1805-1896) was a Belgian soprano.

11) Laure Cinti-Damoreau (1801-1863) was a French singer and composer. 
Already the following year, however, Dorus-Gras sang Isabella. ${ }^{12}$ After Cinti-Damoreau left for the Opéra-Comique, Dorus-Gras completely took over her roles. At the premiere of Les Huguenots (1836), Meyerbeer entrusted her with the coloratura role of Queen Marguerite. It was with Meyerbeer that Dorus-Gras demonstrated her range of abilities as a universal prima donna at a concert held for her benefit when she left the Paris Opera (1845): in Act I of Robert le diable she sang the part of Alice and then that of Isabella in Act II. ${ }^{13}$ In a certain sense, we also see a similar straddling between a pair of female characters in a grand opera in the choice of roles of Kateřina Podhorská, who certainly met Hanslick's definition of an operatic prima donna quoted above: "Her repertoire exhibited such diversity that one did not know whether to classify her as a dramatic or coloratura soprano or as a mezzo-soprano."14 At the Prague premiere of Robert der Teufel, Podhorská sang the role of Alice and Jenny Lutzer played Isabella (incidentally, Meyerbeer held her in great esteem). ${ }^{15}$ Later, Podhorská took over as Isabella, and Henriette Grosserová appeared as Alice. Similarly, the two singers shared the dramatic role of Rachel/Sara and the coloratura role of Eudoxie/Isabella in La Juive. ${ }^{16}$

One might wonder why the role of Eudoxie was to be supplemented with an inserted aria instead of an alternative one. The reason is simple: in Halévy's opera as represented by the authorised, printed score, Eudoxie does not have an aria at all. ${ }^{17}$ This was the case because Halévy, like Meyerbeer, was forced to cut his opera after the premiere (1835) because of its excessive length. Therefore, among other things, he cut the entire first scene of Act III, where Eudoxie was originally to have had several solo numbers: no. 13 (aria), no. 14 (duet with Rachel), and no. 15 (bolero). The piano vocal score contained the numbers in question, but

12) Dorus-Gras stood in at the last moment for Cinti-Damoreau, who refused to appear with the novice MarieCornelie Falcon. With her debut in the role of Alice she became a star of Parisian opera, later as Halévy's Rachel and Meyerbeer's Valentine. See GHEUSI, Jacques - PAZDRO, Michel - RAVIER, Dominique: L'cuure à l'affiche, L’Avant scène. Opéra, opérette 1985, no. 76, June, pp. 102-106.

13) See WHITE, Kimberly: Female Singers on the French Stage, 1830-1848, Cambridge University Press, Cambridge 2018, p. 121.

14) "Ihr Repertoire wies eine derartige Mannigfaltigkeit auf, daß man nicht wußte, sollte man sie als dramatische-, Coloratur- oder Mezzosopransängerin classificiren.” TEUBER, Oscar: Geschichte des Prager Theaters. Von den Anfängen des Schauspielwesens bis auf die neueste Zeit. III., A. Haase, Prag 1888, p. 268 (hereinafter TEUBER).

15) Meyerbeer referred to her as "meine unvergeßliche Isabelle und Margarethe" in a letter dated 28 June 1860 to Franz Freiherr von Dingelstedt, Lutzer's husband. See BECKER, Heinz und Gudrun: Giacomo Meyerbeer. Ein Leben in Briefen, Heinrichshofen, Wilhelmshaven 1983, pp. 226-227, here p. 227.

16) Because Henriette Grosserová was on a musical tour in the summer of 1838, Josepha Eschenová stood in for her at the first six performances.

17) See HALÉVY, Fromental: La Juive. Opéra en cinq actes. Paroles de $M^{r}$ E. Scribe. Musique de [...] Partition. Maurice Schlesinger, Paris [s. a. = 1836]. - Act III does not begin until the scene in the imperial gardens, no. 13 Chœur "Ô jour mémorable[,] ô jour de splendour", p. 367. The first scene was also omitted from the published libretto. See SCRIBE, Eugène: La Juive. Opéra en cinq actes, [...] Musique de M. Halévy, in: SCRIBE, Eugène: Théâtre complet de M. Eugène Scribe, [...] 14, Aimé André, Paris 1835, pp. 389-459 (hereinafter SCRIBE). - Concerning the cuts in the score, see LEICH-GALLAND, Karl: Formes changeantes de La Juive, in: Le Retour de Rachel. Actes du colloque organisé à l'occasion de la reprise de La Juive à l'Opéra de Paris en février 2007, ed. Karl Leich-Galland, Musik-Edition Lucie Galland, Weinsberg 2013, pp. [152]-159 (hereinafter LEICH-GALLAND). 
the full score did not. ${ }^{18}$ Naturally, this intervention harmed the role Eudoxie in terms of its musical importance, making it less rewarding for the coloratura soprano.

\section{Text and music of the aria}

Scribe's and Halévy's heroine, the supposed Jewess Rachel, is in reality a Christian girl. The story of the opera is based on her secret dual identity. The background for the action set in Constance at the time of the ecumenical council in the early $15^{\text {th }}$ century reaches far back into the past. Cardinal de Brogni had once lived a secular life in Rome, and he had a wife and a daughter. After losing them both during an attack by Neapolitan troops, he began a career in the church. He did not learn that the Jew Éléazar had saved the girl from the burning house at the risk of his own life. Years later, the two men meet in Constance. The conflict between the two fathers of one daughter, representatives of irreconcilable religions, one oppressed and the other the oppressor, is presented with extreme heightening of the dramatic situations. Will forgiveness triumph and will the Jew Éléazar reveal the secret of his adopted daughter? Or will he use her as a means of vengeance against Christians for the hardships suffered by his people by allowing her to be put to death before the eyes of her own father? Rachel herself has faced him with this choice. She has fallen in love with a supposedly Jewish painter named Samuel, actually the imperial commander Prince Léopold, husband of Princess Eudoxie, concealed under a false identity. Rachel reveals his deceit and publicly accuses him of a love affair with a Jewish woman. Léopold, Rachel, and Éléazar are imprisoned and face execution. Although she was deceived, Eudoxie still loves her unfaithful husband. She begs Rachel to take back her accusation in order to save Léopold. Rachel and Éléazar refused to be baptised and are determined to die. The crowd's calls for a pogrom against the Jews change Éléazar's determination to save Rachel and cause him to decide to avenge himself on Christians in the person of their highest representative: it is only at the moment of Rachel's execution that Cardinal de Brogni learns from Éléazar that he sentenced his own daughter to die.

Of the scenes in which Eudoxie appears, there was only one conceivable place to add an aria for her: the first scene of Act IV. Eudoxie has asked Cardinal de Brogni for permission to speak with the prisoner Rachel. She is awaiting Rachel's arrival and is prepared to beg her to save her husband Léopold. It is an opportune moment for an aria in which the character can express the thoughts that are within her. The author of the aria's text is unknown. It may have been one of the men of letters active at the Estates Theatre who worked with Škroup, such as Jan Nepomuk Štěpánek, František Valentin Ernst, or Carl Joseph Schikaneder. ${ }^{19}$

18) This is also the reason for the discrepancy between the numbering of scenes in the piano vocal score and the full score. Scene one of Act III was first made available to performers recently in a critical edition. See HALÉVY, Fromental: La Juive. Opera in five acts. Text by Eugène Scribe; edited by Karl Leich-Galland (New edition of selected operas / Fromental Halévy), Alkor-Edition, Kassel - Lucie Galland, Weinsberg 2005.

19) See KUSÁKOVÁ, Lenka - LUDVOVÁ, Jitka: Štěpánek, Jan Nepomuk [entry], in: Česká divadelní encyklopedie [online]. Retrieved from: http://encyklopedie.idu.cz/index.php/\%C5\%A0t\%C4\%9Bp\%C3\%Alnek,Jan_Nepomuk [accessed on 6 March 2021]; SCHERL, Adolf: Schikaneder, Carl Joseph [entry], in: ibid, 
To give an idea of what was added in Prague, below is a comparison of the text of the first scene from Scribe's printed libretto, the German version by Seyfried and Hofmann, and Škroup's manuscript score..$^{20}$

\author{
Scribe \\ Acte IV. \\ Un appartement gothique qui \\ précède la chambre du concile. \\ Scène première.
}

Eudoxie, et plusieurs gardes à qui elle présente un papier.

Du prince de Brogni voici

l'ordre suprême.

Il me permet de voir Rachel

quelques instants.

(Les gardes sortent par la porte à droite.)

Mon Dieu! pour délivrer l'infidèle que

j'aime,

Viens soutenir ma voix et dicter mes

accents.

Que je sauve ses jours! et puis qu'après je meure!

\author{
Seyfried \& Hofmann \\ Vierter Aufzug. \\ Gotisches Gemach vor der \\ Gerichtshalle. \\ Erste Scene.
}

Isabella. Mehrere Wächter.

Isabella (zu den Wächtern).

Ihr seht hier die Befehle des

Comthurs;

Die hier gefangen ist, erlaubt er mir zu sehen.

(Die Wächter entfernen sich rechts.)

Den Falschen zu befrei'n, den ich im Herzen Den falschen zu befrein, den ich im Herzen trage,

Gib meiner Schwäche Muth, gib meiner Zunge Kraft.

Ist frei er, mag sich mein Geschick entscheiden.

\author{
(Unidentified author)
}

Isabella

Ihr sehet hier den Befehl des Eomthurs

Cardinals[.]

Die hier gefangen ist[,] erlaubt er mir zu sehn!

trage!

gieb meiner Schwäche Muth[,] meinen

Worten Kraft!

Rett ich ihn vor Gefahr[,] mag mein

Geschick sich entscheiden!
Ja selbst das schwerste will ich dulden, geht er nur wieder frei einher!

Denn immer noch ist er mir theuer!

fühlt gleich sein Herz für mich nicht mehr!

Kann ichs auch tragen! ihm

zu entsagen, o nein.

Doch muß es sein.

Als für fara Recha er erglühte!
und dieß treue Herz verstieß[,]
welkte meiner Liebe Blüthe
sank dahin mein Paradieß!
Wüßte er[,] wie ich gerungen,
sicher trübte sich sein Blick,
doch mein Herz hab ich bezwungen,
neu erblühen soll sein Glück.
Darf ich jetzt auch mein ihn nicht mehr
nennen,
eil ich doch zur Rettung froh herbei!
und in Saras Rechas Arm soll er erkennen,
daß dieß Herz ihn liebte wahr und treu!
Sey beglückt[,] Geliebter[,] ich entsage
deiner Liebe! ich will einsam stehn!
meiner Brust entschlüpfet keine Klage[,]
werd ich dich nur froh und glücklich sehn!

http://encyklopedie.idu.cz/index.php/Schikaneder,_CarLJoseph [accessed on 6 March 2021]; LUDVOVÁ, Jitka: Ernst, Ferdinand Valentin [entry], in: ibid, http://encyklopedie.idu.cz/index.php/Ernst,_Ferdinand_ Valentin [accessed on 6 March 2021].

20) The text has been reconstructed to the form in which it was probably inserted into the libretto, i.e. it is reproduced without the repetition of verses and words and other changes arising from the musical setting. Concerning the changes to the names of the characters, see the section below about performances of the aria. 
In the text of the aria, Isabella laments that Arnauld no longer loves her. She will show her love for him by giving him liberty. Such a decision presupposes that, unlike in Scribe's version where Léopold is the husband of Eudoxie, in the censored version Arnauld and Isabella are only betrothed. It was not permissible in Austria to portray real marital infidelity on stage. ${ }^{21}$ Isabella can save Arnauld only by softening Sara's heart with pleas that she take back her accusation and deny her relationship with a Christian. And that is what happens in the duet of Eudoxie/Isabella and Rachel/Sara. Of course, from the point of view of the libretto's plot, Isabella's selfless intent expressed in the aria, namely that her unfaithful lover find repose in the embrace of her rival, is unthinkable to the point of absurdity. After all, a romance between a Christian and a Jew meant the risk of execution for both. Derailing the story's chain of causality in this way represents an excess with respect not only to Scribe, but also to the German librettists Seyfried and Hofmann. The text of the inserted aria was conceived as encompassing almost idyllic sentiments of happy and unhappy love while completely overlooking of the dramatic context, probably in order to allow the fast section of the aria to end joyously. Jubilation over the saving of a beloved person at the cost of sacrificing one's own life is nothing unusual in opera, and in Scribe's original Eudoxie clearly expresses such a perspective: "Let me save his life! And then let me die!"22 Eudoxie expects death even after achieving her intention of freeing Léopold. She parts with Rachel with the words: "Like you, Rachel, I too hope that death will soon put an end to my misery..." Any portrayals of or reflections upon suicide on stage in Austria were subject to strict scrutiny by the censors, ${ }^{24}$ so Seyfried and Hofmann avoided even hinting at anything of the kind. In the version conforming to censorship, the mere thought of her ending her life is out of the question: "Once he is free, let my fate be decided."25 And Isabella sees her fate as departure for a convent: "Let me be confined in a dark cell; that is the right place for an ailing heart."26

The irregular verses at the beginning are clearly intended for the musical setting of a recitative (Ja selbst das schwerste will ich dulden [...] Doch muß es sein). The verses of the aria itself are divided into two parts. Two quatrains are in trochaic tetrameter and two are in trochaic pentameter, all with an alternating rhyme scheme. The open vowel [a]

21) Cf. the general directives for censorship as formulated in the 1795 memorandum of state counsellor Franz Karl von Hägelin for theatrical censorship in Hungary, which remained in force until 1848. The directives are published in GLOSSY, Carl: Zur Geschichte der Wiener Theatercensur, in: Jahrbuch der Grillparzer-Gesellschaft, vol. 7, 1897, pp. 238-340 (hereinafter GLOSSY). See in particular the section "Gebrechen des Stoffes in Absicht auf die Sitten”, pp. 317-320. Newly reprinted in BACHLEITNER, op. cit. in footnote no. 3, pp. 438-462.

22) "Que je sauve ses jours! et puis qu'après je meure!” SCRIBE, op. cit. in footnote no. 17, p. [439].

23) "Ainsi que toi, Rachel, le trépas, je l'espère, || Aura bientôt terminé ma misère..." SCRIBE, op. cit. in footnote no. 17, p. 443.

24) See GLOSSY, op. cit. in footnote no. 21, pp. 315, 323-324; BACHLEITNER, op. cit. in footnote no. 3, pp. 447-448, 452-453.

25) "Ist frei er, mag sich mein Geschick entscheiden." SEYFRIED, Ignaz Ritter von - HOFMANN, Georg von: Die Jüdinn. Große Oper in fünf Aufzügen, mit Divertissement. Nach dem Französischen des Scribe, von [...] Musik von Halevy. J. B. Wallishausser, Wien 1836, p. [43] (hereinafter SEYFRIED - HOFMANN).

26) "Mich umschließe eine düst're Zelle; || Ein krankes Herz hat dort die rechte Stelle." SEYFRIED HOFMANN, op. cit. in footnote no. 25, p. 46. 
(in pronunciation) in masculine half rhymes with the diphthongs ei [aI] and eu [or ] "herbei, treu" in the first strophe in pentameter and the long open vowel [a:] in the penultimate foot of its fourth verse "wahr und true" obviously suggest that the one-syllable word in question be set appropriately with a coloratura passage, along with the usual high notes of the tonic or dominant at the conclusion of the aria.

Škroup had undoubtedly asked that the text be arranged so he could set it to music in the form of a two-part aria with a slow section (recitativo, adagio) and a fast one (cabaletta). ${ }^{27}$ At that time, two-part arias were in common use for the big vocal numbers that composers generally employed in intensely dramatic situations. In the score of La Juive, the aria is incorporated into no. 16: Scène et duo. In Škroup's autograph, there is no title on the first page of notation, which is designated as no. 13. This shows that several numbers were omitted from the Prague version. Škroup carried over the beginning of the composition from Halévy, but with some changes to the text by Seyfried and Hofmann and to the vocal line of the German recitative up to the end of bar 26. From there, the actual inserted composition begins in the form of a two-part aria with frequent recitatives (bars 27-42) and a slow section in a strophic two-part form (43-81), which proceeds without a tempo di mezzo linking passage to a fast section (82-186). The fast section does not use the standard structure of the Italian cabaletta, which is repeated literally after a brief episode; instead it is structured in the manner usual for French and German operas in ternary form with

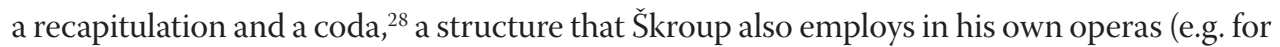
Libuše's arias in Libušin sňatek - Libuše's Marriage, or Marie's in Columbus) ${ }^{29}$ The return to Halévy's composition is realised by two bars of chromatic modulation from the aria's main key E major to A flat major.

Formal layout:

\begin{tabular}{|l|l|l|l|l|l|l|}
\hline Composer & Section & & Bars & $\begin{array}{l}\text { Metre and } \\
\text { tempo }\end{array}$ & Key & Text incipit \\
\hline Halévy & & & $1-26$ & C, Moderato & $\mathrm{g}$ & Ihr sehet hier den Befehl \\
\hline Škroup & Recitative & & $27-42$ & Recit & $\mathrm{b} \rightarrow \mathrm{E}$ & Ja selbst das schwerste \\
\hline & Slow section & $\mathrm{a}$ & $43-55$ & $2 / 4$, And $^{\mathrm{ve}}$ & $\mathrm{E} \rightarrow \mathrm{B}$ & $\begin{array}{l}\text { Als für Sara er erglühte! } \\
\text { (incipit: musical } \\
\text { example no. 1) }\end{array}$ \\
\hline
\end{tabular}

27) DÖHRING, Sieghart: Formgeschichte der Opernarie vom Ausgang des achtzehnten bis zur Mitte des neunzehnten Jahrhunderts, George, Itzehoe 1975 (hereinafter DÖHRING). - For a characterisation of the twopart aria and of its sections, see JOERG, Guido Johannes: Glossar, in: Verdi Handbuch, eds. Anselm Gerhard - Uwe Schweikert, Metzler - Bärenreiter, Stuttgart - Weimar 2013, pp. 698-716.

28) Concerning the form of the two-part aria in French and German opera, see DÖHRING, op. cit. in footnote no. 27 and SCHNEIDER, Herbert: Les airs vocaux des opéras d'Halévy, in: CLAUDON, op. cit. in footnote no. 3, pp. 169-192; SCHNEIDER, Herbert: Cavatine, Cantabile und Cabaletta in den Opéras-comique von Scribe, Auber und einigen ihrer Zeitgenossen, in: Musiktheater im Fokus, eds. Sieghart Döhring - Stefanie Rauch, Studio Verlag, Sinzig 2014, pp. 497-518.

29) See ŠKROUP, František: Libušin sňatek, Act III, no. 16. Aria; Columbus, Act III, no. 19. Recitativo \& Aria con Coro. 


\begin{tabular}{|c|c|c|c|c|c|c|}
\hline Composer & Section & & Bars & $\begin{array}{l}\text { Metre and } \\
\text { tempo }\end{array}$ & Key & Text incipit \\
\hline & & $b$ & $55-63$ & & B & $\begin{array}{l}\text { Wüßte er, wie ich } \\
\text { gerungen }\end{array}$ \\
\hline & & $\mathrm{a}$ & $63-73$ & & $E \rightarrow B$ & Als für Sara er erglühte! \\
\hline & & $b^{\prime}$ & $73-81$ & & B & $\begin{array}{l}\text { Wüßte er, wie ich } \\
\text { gerungen }\end{array}$ \\
\hline & Fast section & c & $82-98$ & C, Allo: & $\mathrm{E} \rightarrow \mathrm{F}$ sharp & $\begin{array}{l}\text { Darf ich jetzt auch } \\
\text { mein ihn nicht mehr } \\
\text { nennen (incipit: musical } \\
\text { example no. 2) }\end{array}$ \\
\hline & & $d$ & $98-130$ & & B & Sei beglückt Geliebter \\
\hline & & c & $131-149$ & & $E$ & $\begin{array}{l}\text { Darf ich jetzt auch mein } \\
\text { ihn nicht mehr nennen }\end{array}$ \\
\hline & Coda & k & $149-186$ & & E & daß dies Herz ihn liebte \\
\hline & Transition & & $187-189$ & $\begin{array}{l}\text { Andante con } \\
\text { moto }\end{array}$ & $\mathrm{E} \rightarrow \mathrm{A}$ flat & \\
\hline Halévy & & & $27=$ Š 189 & And ${ }^{\text {te }}$ con moto & A flat & \\
\hline
\end{tabular}

1.
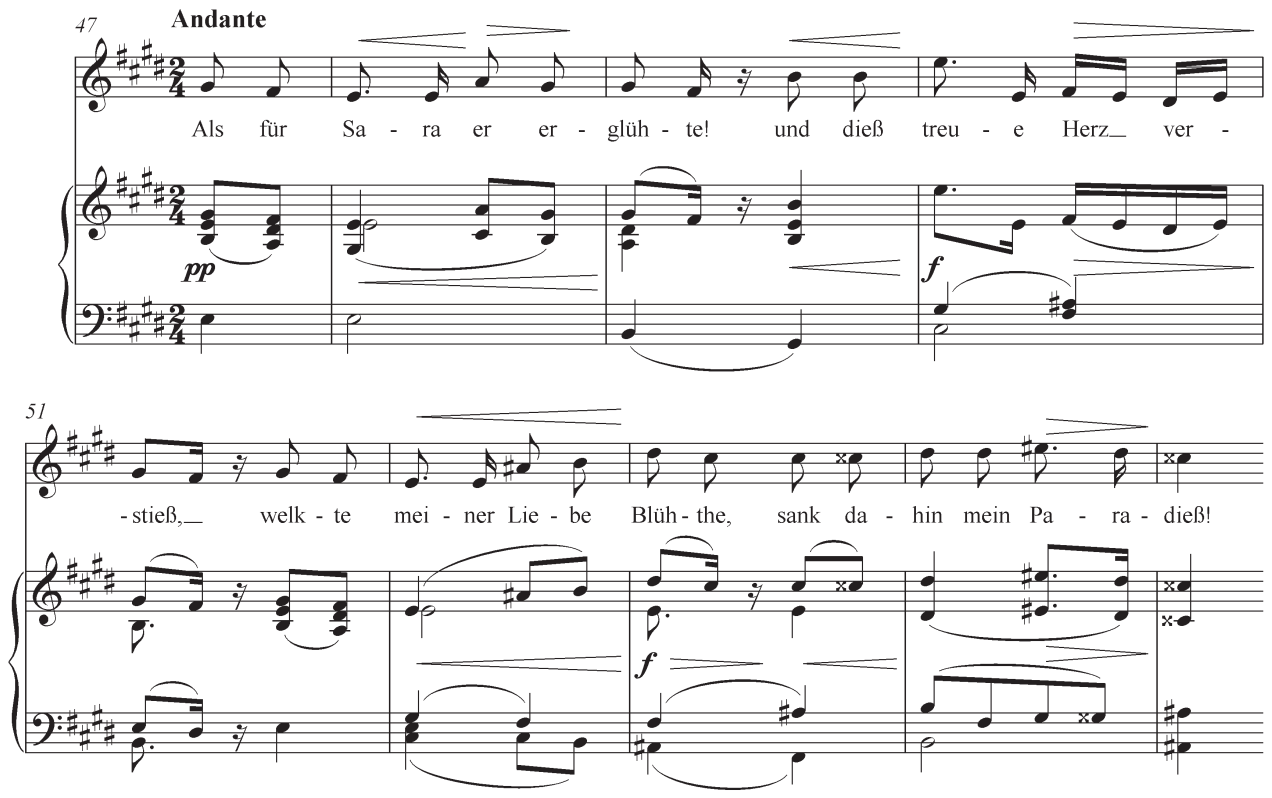


\section{2.}

$82 \quad$ Allegro
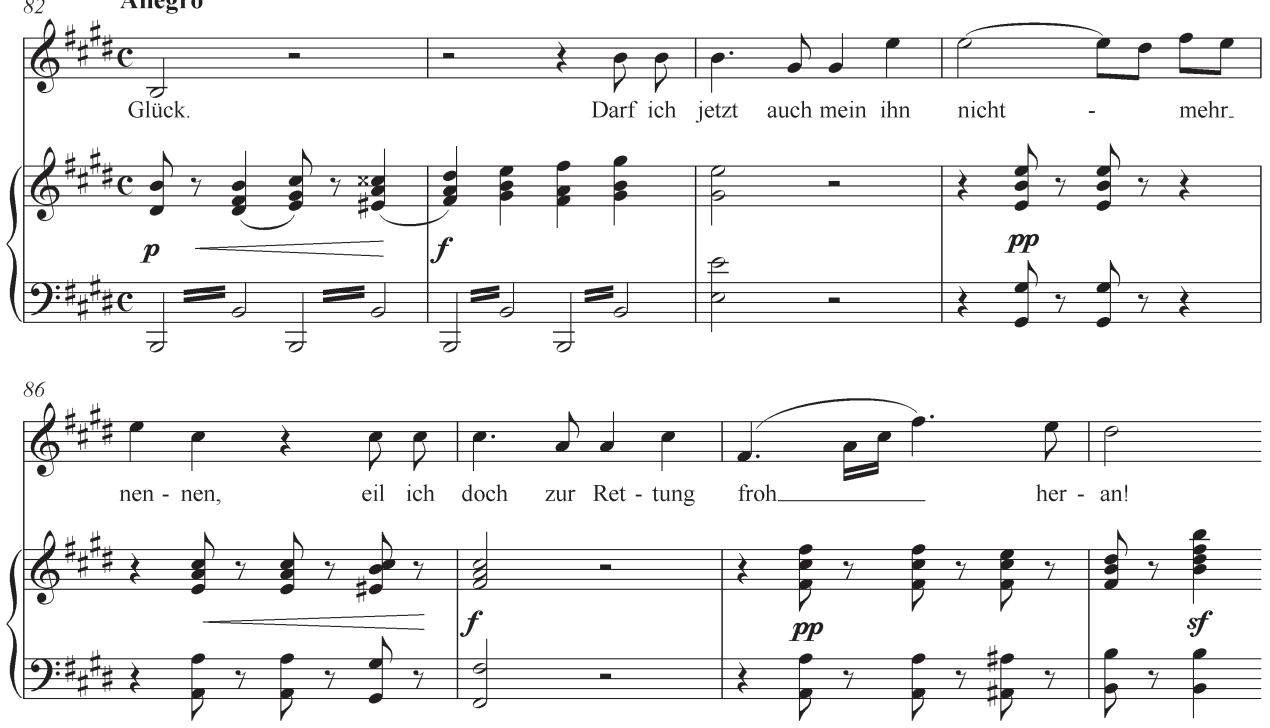

In an aria written for a particular performer, we might be interested in whether the vocal part contains features by which the composer wished to take advantage of some of the virtues of that person's vocal artistry. In view of Podhorskás reputation as a superb coloratura singer, this would tend to be passages that demand virtuosity. Critics especially admired her "beautiful trills and elegantly executed triplet passages". ${ }^{30}$ According to a period account, her singing was characterised by the exemplary "precision with which she was able to arrange tones one after another like a string of pearls even within the shortest spans of time". ${ }^{31}$ SKkroup adorned the fast section with coloratura passages. Overall, the range of the aria corresponds more to that of a mezzo-soprano $\left(b-g\right.$ sharp $\left.{ }^{2}\right)$, but in the coda the range rises all the way up to $\mathrm{c}$ sharp ${ }^{3}$. There are trills, brilliant triplet passages, and a two-octave descending chromatic scale:

30) "In diesem zweiten Akte [Hérold's opera Ludovic completed by Halévy] sprach eine einzige Arie, die Mad. Podhorsky sang, durch ihren herrlichen Triller und die elegant ausgeführten Triolenpassagen an, aber - diese Arie war aus Auber's ,Lestocq' eingelegt.” Nachrichten. Prag, Allgemeine musikalische Zeitung, vol. 40, 1838, no. 14 (4 April), cols. 221-225, here 224.

31) "Was an ihrem Gefang musterhaft genannt werden mußte, war die Accuratesse, mit welcher sie selbst in den kleinsten Zeittheilchen die Töne wie an einer Perlenschnur an einander zu reihen verstand, [...]" TEUBER, op. cit. in footnote no. 14, p. 176. 
3.

156 tronnminnminninn

$Q_{0}=0$.

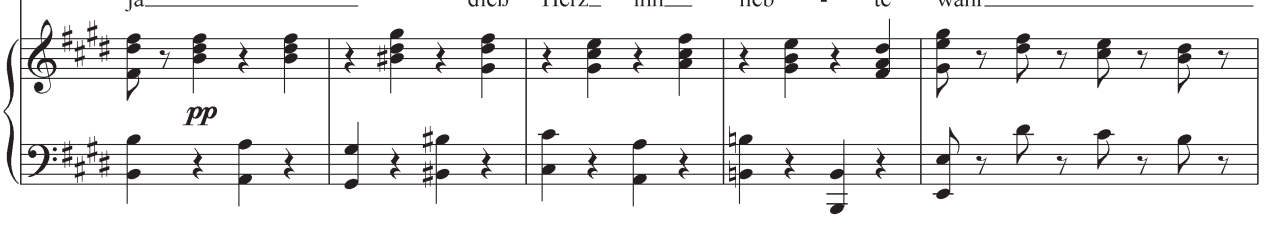

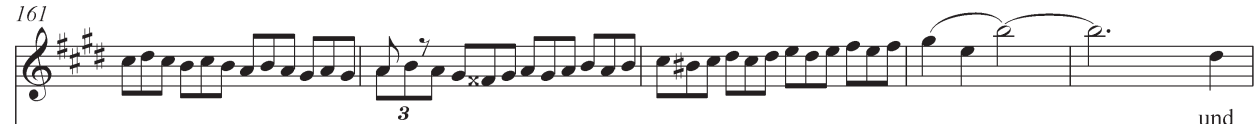

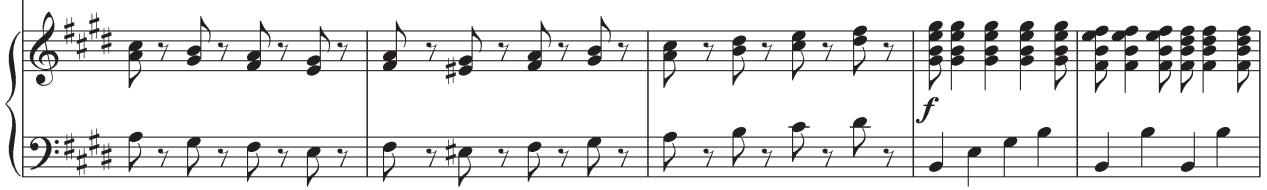

$\mathrm{Q}_{\mathrm{tru}}^{166}$

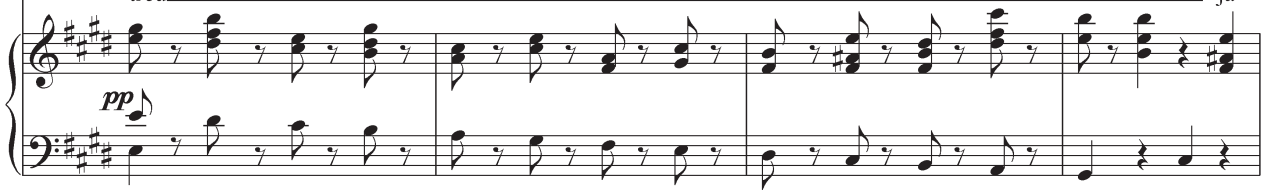

$\oint_{\text {wahr }}^{170}$

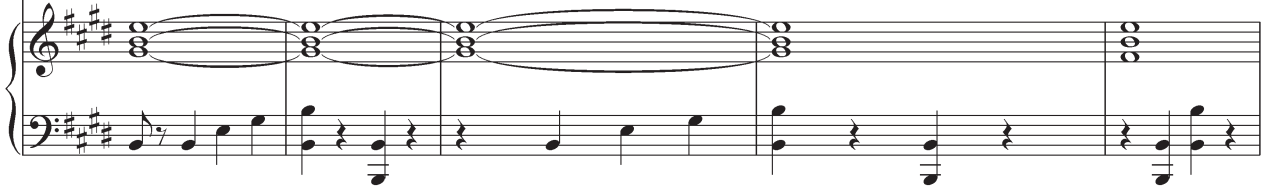

$Q_{0}^{175}$

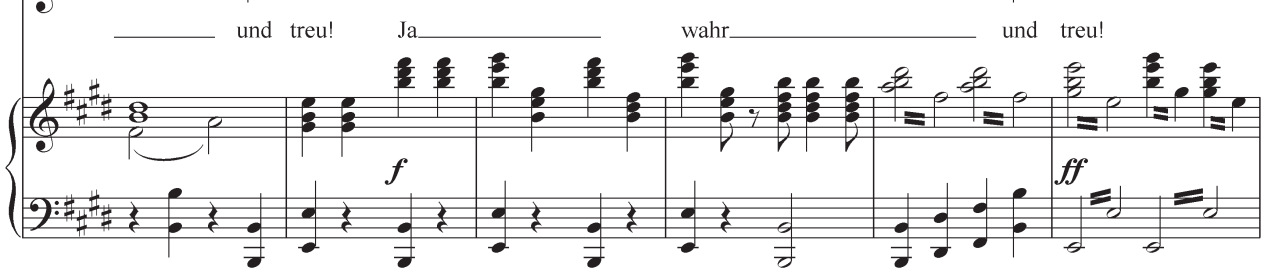




\section{Performances}

Kateřina Podhorská inserted arias from other operas into her roles, and she also sang inserted arias by other composers at concerts. For example, she sang an Italian aria in Boïeldieu's opera Les Deux nuits:

"That evening, one number received stormy applause - an Italian aria that Mrs. Podhorská inserted into Act II, which stood out as something very strange and out of place in the French context."32

In another case she inserted an aria from Halévy's opera Guido et Ginevra, ou La Peste de Florence into Adam's opera Le Fidèle berger:

"Apart from one chorus of fishermen in Act I and one cavatina inserted by Mrs. Podhorská and taken from The Plague of Florence by Halévy, no number was applauded, and the opera began and ended in silence."33

One may therefore surmise that Škroup may have composed the aria for her at her request. Apparently he had been contemplating writing the aria from the moment the decision was made to produce the opera. In any case, the text of the aria must have already been contained in the manuscript of the libretto submitted to the censors for approval in June $1838 .{ }^{34}$ The autograph score bears the date 23 July, i.e. two days before the premiere. Even given how quickly operas were produced in those days, it does not seem likely that the aria was expected to be sung already at the premiere. Contrary to the customs of the day, the theatrical poster did not draw attention to it. To the contrary, that it did not belong to Halévy's opera was probably supposed to be concealed from the public. From press reports, it can be inferred that Podhorská did not yet sing the inserted aria at the premiere, but that it was first heard at a benefit performance, for which the aria had probably been intended from

32) "Den stürmischsten Beifall des Abends erhielt eine - italienische Arie, welche Mad. Podhorsky im zweiten Akte eingelegt hatte und die sich auf dem französischen Grunde gar sonderbar und fremdartig ausnahm.” Z. 17.: Prag (Beschluß), Allgemeine musikalische Zeitung, vol. 41, 1839, no. 49 (4 Dec.), cols. 986-987, here 986.

33) "Tranne un coro di pescatori nel primo atto, e una cavatina introdotta per la signora Podhorsky e tolta dalla Peste di Firenze di Halevy, nessun pezzo fu applaudito, e l'opera incominciò e si chiuse nel silenzio." Gazzetta teatrale e musicale. Praga, La Fama. Giornale di scienze, lettere, arti, industria e teatri, vol. 4, 1839, no. 37, (27 March), p. 148.

34) See Národní archiv Praha, collection Presidium českého gubernia, book 220 Censurirte Theaterstücke für die Prager Bühne 1838-1843 [n.p.]: "Nro. 31. Die Jüdin Große Oper in 5 Akt. mit Divertissement Nach dem Französischen des Scribe v Seyfried \& Hofmann. Musik von Halevy. dto. [=Manuskript] dto. [=Darf aufgeführt werden] Tag der Erledigung 18/6 [1838]". The opposite page bears the pencil inscription: "Einlags Duett zur Jüdin: Sara P 4/p - 5/p darf aufgef werden 4 Sept. 838". - This may have reflect the fact that the duet of Isabella and Sara had first been shortened in Prague, and Henriette Grosserová wanted to sing the version she had sung on 31 July 1838 at her guest appearance in Dresden. However, the expansion of the text related thereto (also possibly from a translation by Karl Augustus Freiherr von Lichtenstein or Friederike Ellmenreich) required approval from the censors, and this was granted five days before the Prague appearance of Grosserová in the role of Rachel/Sara. Nonetheless, all of these ideas are mere hypotheses because the performance material for Die Jüdin at the Estates Theatre from that time has not been preserved. 
the beginning. The performance for Podhorskás benefit had originally been announced for 27 July, but it was postponed until 3 August because the singer in the role of Sara was ill.

"A performance for the benefit of our leading tenor Demmer was plentifully attended, but its reprise was unfortunately postponed because of the illness of Miss Eschen."35

The singing of the aria at the benefit performance for Podhorská is documented by a Prague correspondent to the journal Wiener Zeitschrift für Kunst, Literatur, Theater und Mode, who also expresses his surprise that the local reviewer did not notice it at all. By doing so, he also explicitly demonstrates that the review of the benefit performance by Anton Müller in the journal Bohemia is not reliable in reference to the inserted aria:

"It was quite odd that at the second performance of Halévy's opera 'The Jewess', the overture was replaced by a mere musical introduction. On the other hand, Mr. Demmer sang Eleazar's big aria in Act III, ${ }^{36}$ which he had omitted the first time. (Mrs. Podhorska also inserted an aria that was pretty but entirely unfamiliar.). The local correspondent who reviewed both productions and was unaware of any additions or omissions had only this to say: 'just as at the first performance, the overture (which was not played) went by without attracting much attention from the public."'37

A critic for the Leipzig journal Allgemeine musikalische Zeitung who was clearly quite familiar with the work he was reviewing did not fail to notice the peculiarities of the Prague performance.

"Mrs. Podhorská (Isabella) did what she could with her quite ungrateful role; her aria in Act IV was cut to the point that it was unrecognisable (just as the whole opera was cut in an incomprehensible and inexcusable manner), and at later performances an aria was inserted that quite certainly is not by Halévy. It seems that it is based on a Mozartean motif that has been elaborated in the modern Italian manner."38

35) "Die Vorstellung, das Benefize unseres ersten Tenoristen Demmer, war zahlreich besucht, leider wurde die Wiederholung derselben durch die Krankheit der Dem. Eschen unterbrochen.” MARENGO: Prager Zustände. (Schluß.), Allgemeine Theaterzeitung und Originalblatt für Kunst, Literatur, Musik und geselliges Leben, vol. 31, 1838, no. 172 (28. 8.), p. 767.

36) Recte "in Act IV".

37) "Sonderbar genug wurde bey der zweyten Vorstellung von Halevy's, Jüdin' statt der Ouvertüre nur eine musikalische Introduction substituirt, dagegen sang Hr. Demmer die große Arie des Eleazar im dritten Acte, die er das erste Mal ausgelassen hatte. (Auch Mad. Podhorsky hatte eine hübsche, aber ganz fremdartige Arie eingelegt.) Ein hiesiger Berichterstatter, der über beyde Productionen referirte, und weder dies plus noch jenes minus inne geworden war, meint bloß: ,die (nicht aufgeführte) Ouvertüre ging, wie bey der ersten Vorstellung, ohne bedeutende Theilnahme des Publicums vorüber.'” Correspondenz-Nachrichten. Prag, im August 1838. (Schluß.), Wiener Zeitschrift für Kunst, Literatur, Theater und Mode [vol. not stated], 1838, no. 107 (6 Sept.), p. 854. - Cf. "Die Ouvertüre ging wie bei der ersten Vorstellung ohne bedeutende Theilnahme des Publicums vorüber." [MÜLLER, Anton]: Theater und geselliges Leben. Theaterbericht vom 3. August, Bohemia, vol. 15, 1838, no. 93 (5. 8.), pp. [3]-[4], here p. [3].

38) "Mad. Podhorsky (Isabella) machte aus ihrer ziemlich undankbaren Partie, was nur immer daraus zu gestalten ist; ihre Arie im vierten Akte war bis zur Unkenntlichkeit gekürzt (wie überhaupt die ganze Oper auf unbegreifliche und unverzeihliche Weise zusammengestrichen war), und in den Reprisen legte sie eine Arie ein, die ganz gewiss nicht von Halévy ist. Es scheint ein Mozart’sches Motiv zum Grunde zu liegen, das 
We may assume that the aria remained a part of the performances of Die Jüdin at the Estates Theatre. Changes to the vocal part and various corrections and retouches in the orchestral parts were undoubtedly required by performance practice. The visible wear of the score also shows that it was used rather frequently.

We also have one report that Podhorská sang the aria at a benefit concert for the Institute for Care and Employment of the Adult Blind in Prague on 26 February 1842:

"Mr. Strakatý and Mrs. Podhorská received a noisy ovation for their performances of the song 'Do dálky' [Into the Distance], sensitively composed by J. N. Škroup, and of an aria by František Škroup composed as an insertion for Halévy's opera 'The Jewess'; [...]"39

It is not known whether Škroup's aria was performed anywhere outside of Prague and environs. At the first performance of Die Jüdin in Munich on 18 April 1844, an aria for Eudoxie/Isabella "written in a foreign hand" is said to have been inserted into the opera. ${ }^{40}$ Singing the part of Isabella there was Jindřiška Rettigová (Henriette Rettich), a former ensemble member at the Estates Theatre and later a guest there. ${ }^{41}$ Because of a lack of details, one cannot speculate about the nature or authorship of the aria, ${ }^{42}$ but the mere fact that this occurred shows that the lack of an opportunity for the leading coloratura singer

modern italienisch durchgeführt ist.” Z. 17.: Prag (Beschluss), Allgemeine musikalische Zeitung, vol. 40, 1838, no. 39 (26 Sept.), cols. 646-647, here 647. - Eudoxie (Isabella) has no aria in Act IV. The reviewer may have meant the arioso at the beginning of the duet no. 16 (Andantino espressivo, 3/4, F major: "Ah! pour celui qui m'a trahie"), which is found only in the piano vocal score and not in the printed orchestral score (see HALÉVY, Fromental: La Juive. Opéra en 5 actes. Paroles de Mr Scribe. Musique de ... Partition piano \& chant, Henry Lemoine, [Paris] [s. a.], p. 312 ff.).

39) "Das Lied ,in die Ferne', von J. N. Škraup (empfindungsvoll durchcomponirt), eine als Einlage in Halevy's ,Jüdin' componirte Arie trugen Hr. Strakaty und Mad. Podhorsky unter lautem Beifalle vor; [...]." T.: Concerte vom 26. und 27. Februar, Bohemia, vol. 15, 1842, no. 26 (1 March), p. [4].

40) "écrit par une main étrangère". LEICH-GALLAND, op. cit. in footnote no. 17, p. 156.

41) See ZENGER, Max: Geschichte der Münchener Oper, Verlag für praktische Kunstwissenschaft Dr. F. X. Weizinger \& Co., München 1923, pp. 307-308; BAJGAROVÁ, Jitka: Rettigová, Jindřiška [entry], in: LUDVOVÁ 2006, op. cit. in footnote no. 2, pp. 442-444, and in: Česká divadelní encyklopedie [online]. Retrieved from: http://encyklopedie.idu.cz/index.php/Rettigov\%C3\%Al,_Jind\%C5\%99i\%C5\%Alka [accessed on 26 Feb. 2021].

42) The press reports after the Munich premiere of Die Jüdin do not mention the inserted aria, and they treat Isabella as a minor role. Cf. Feuilleton der Kunst. Theater, Münchener Conversationsblatt, vol. 5, 1844, no. 32 (20 April), p. 128; Feuilleton der Kunst. Theater, ibid, no. 33 (25 April), p. 132; Notizen über Kunst. Theater, Der Bayeriche Landbote, vol. not stated, 1844, no. 112 (21 April), p. 484; Königliches Hof- und Nationaltheater, Der Bayerische Eilbote, vol. not stated, 1844, no. 48 (21 April), p. 391; Königliches Hof- und National-Theater, ibid, no. 49 (24 April), p. 402; Nichtpolitische Zeitung. München, 19. Juli [!], Neue Würzburger Zeitung, vol. not stated, 1844, no. 112 (22 April), p. [4]; G-f.: Salon, Münchener Tagblatt, vol. 18, 1844, no. 113 (23 April), p. [531]; Salon, ibid, no. 114 (24 April), p. [535]; Theaternotizen, Münchener politische Zeitung, vol. not stated, 1844, no. 99 (25 April), pp. 394-395; Correspondenz-Nachrichten. Aus München, 21. April, Allgemeine Theaterzeitung, vol. 37, 1844, no. 100 (25 April), p. 415; Aus München, ibid, no. 104 (30 April), p. 432. - The remainder of the performance material for Die Jüdin from the Royal Court Opera in Munich kept at the Bayerische Staatsbibliothek gives no hint of the existence of an inserted aria for Isabella. See Die Jüdin. | Oper in fünf Aufzügen von Halevy. [Einbandetikett von 14, Bd. 1]; [Historisches Aufführungsmaterial der Bayerischen Staatsoper]. 


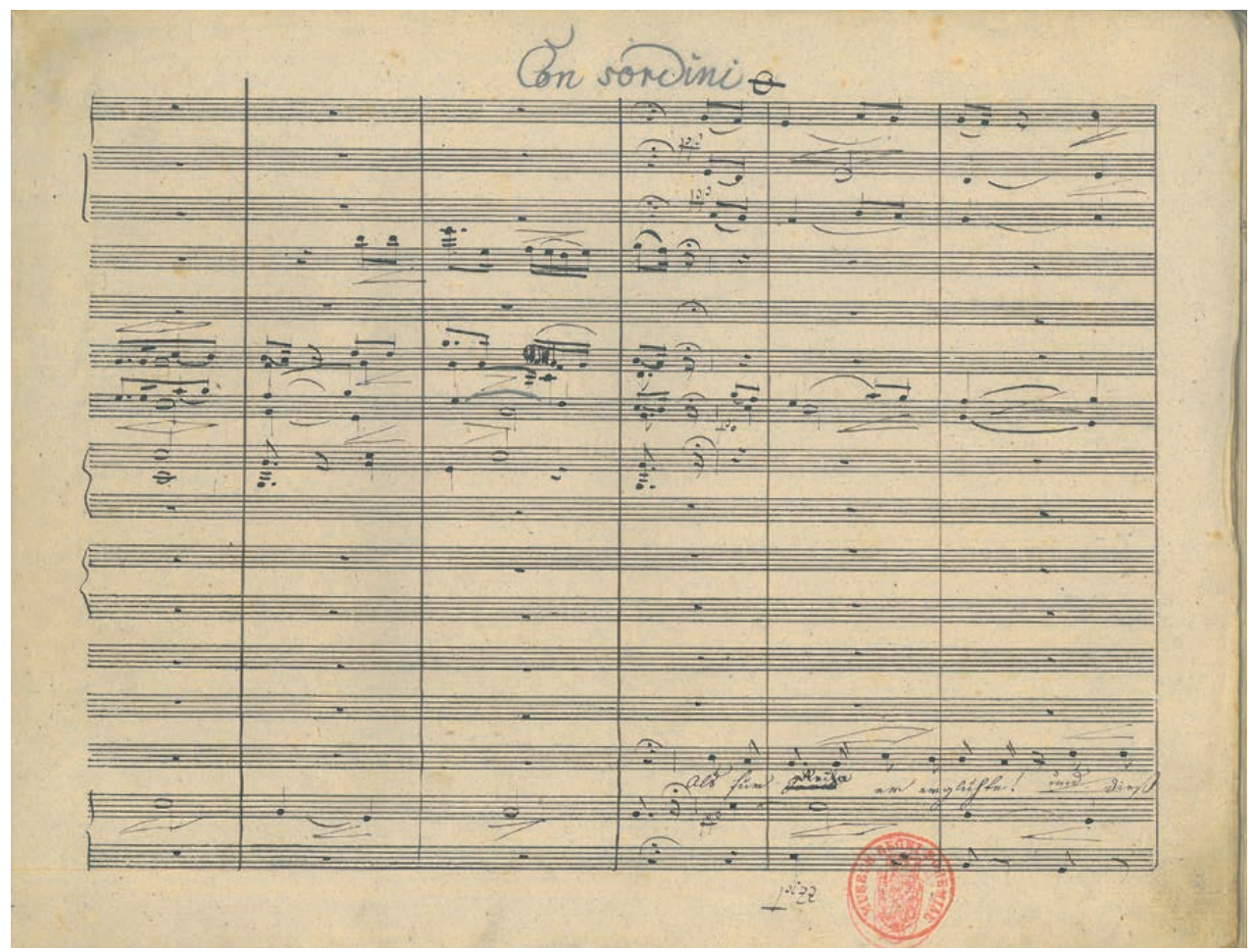

\section{František Škroup: Aria for the opera La Juive / Árie k opeře La Juive}

Autograph, score, p. 11, 1838 / Autograf, partitura, s. 11, 1838

NM-CMH XIXE 60

to demonstrate her ability in the role was something felt not only in Prague, and that the problem was overcome in a similar manner.

In Škroup's score there is noteworthy documentation that the aria was also sung after Podhorská left the theatre in February 1849. In the vocal text, Škroup used pen and ink to cross out the names of the characters "Comthur" and "Sara", corresponding to the censured version by Seyfried and Hofmann, and replaced them with "Cardinal" and "Recha". After the abolishment of censorship during the Revolutions of 1848, it was possible to perform operas in Prague in an uncensored form. This was also done with Halévy's La Juive, in which it sufficed to return the action from the $13^{\text {th }}$ century and an unspecified location to the ecumenical Council of Constance in the $15^{\text {th }}$ century and to replace the imaginary commander of the Order of the Knights Templar with the original "historical" figure of the Cardinal de Brogni to reveal more clearly to the public the conflicts between the Jewish and Christian religions, which had previously been weakened and distorted by the censors' alterations. ${ }^{43}$ When at a performance on 8 December 1849 Miss Byri appeared not as Isabella,

43) After the revolution in Austria was suppressed, but before the final implementation of neo-absolutism, freedom of expression in the theatre was again limited by order of Interior Minister Alexander von Bach on 25 November 1850 with the promulgation of the Theatre Act. In particular, this meant a return to theatrical censorship, and in the case of Halévy's opera, a return to the censored version. 
the niece of the vice-regent, but as Eudoxia, niece of Emperor Sigismund, she apparently also sang the inserted aria. At revivals of Die Jüdin, the aria probably remained available as an optional insertion. In any case, it did not survive Škroup's departure from the Estates Theatre in the autumn of 1857 . Fortunately, the autograph score of the aria did not disappear with the rest of the performance material, and it was preserved in the composer's estate.

Certainly, František Škroup and the local author of the verses could not stand alongside Fromental Halévy and Eugène Scribe as equal partners. Nonetheless, by their effort to patch over an objective dramaturgical error in the opera La Juive, they made a significant and creative contribution to the work's reception in Europe. From this perspective, Škroup's aria represents his only such effort so far known, and it is unquestionably worthy of publication and of modern-era performances. At the same time, the composer of the aria was paying a compliment to a singer who by then had been one of the finest performers of the opera company at Prague's Estates Theatre for the extraordinarily long period of 27 years and whose artistry had also contributed to the successful reception of works of the French grand opera genre.

Address: Milan Pospísil, Nadace pro dějiny kultury ve střední Evropě / Association for Central European Cultural Studies, U Třešňovky 8, 18200 Praha 8, Czech Republic

E-mail:pospisil.milan.phdr@seznam.cz 
11) $4 8 0 \longdiv { 1 1 1 }$
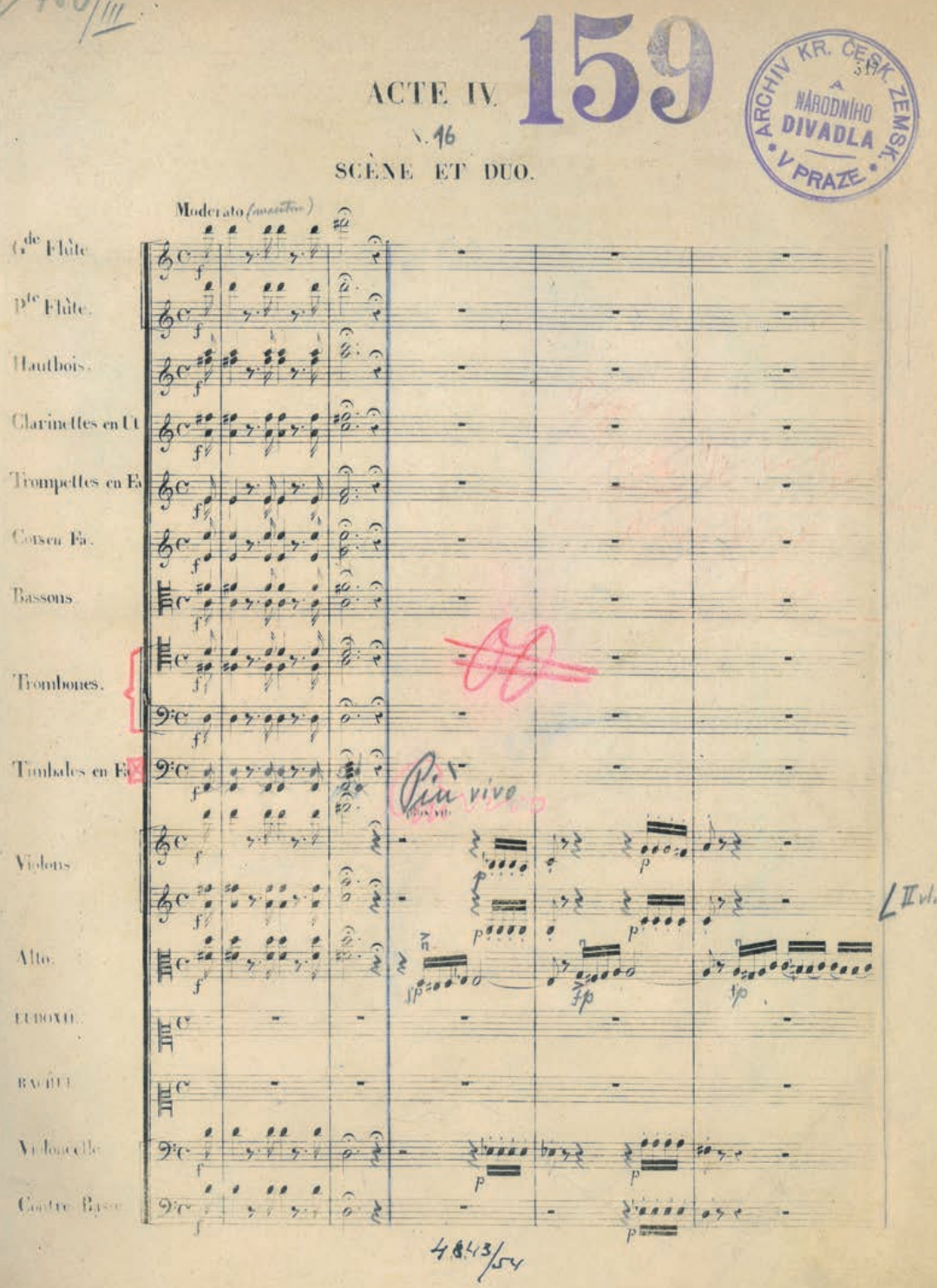

\section{Jacques Fromental Halévy: La Juive}

Print, Paris, 1836, score, beginning of Act IV / Tisk, Paříž, 1836, partitura, začátek 4. aktu

Music Archive of the National Theatre, H 159/P1-III / Hudební archiv Národního divadla, H 159/P1-III 


\section{Árie Františka Škroupa do Halévyho opery La Juive}

\section{Milan Pospiśil}

\section{Pramen}

Ve sbírce hudebněhistorického oddělení Českého muzea hudby (dále jen NM-ČMH) se nachází pod signaturou XIX E 60 rukopis hudebniny s titulní stranou nadepsanou:

Einlags=Arie || zu der Oper || Die Jüdinn || componirt von || F. Skraup. || Kapellmeister am k. st. Theater zu Prag. || [Text zaškrtaný perem k nečitelnosti] || Prag, am 23 July 1838

$\mathrm{Na}$ titulní straně $\mathrm{v}$ levém horním rohu je nalepen obdélníkový tištěný štítek Museum Regni Bohemiae s českým lvem na erbu a s korunou. Štítek má perem napsanou signaturu XIX E 60. Dole uprostřed je kulaté červené razítko Museum Regni Bohemiae s českým lvem. Vpravo dole připsáno tužkou: Darovala Bož. Škroupová 1921.

Rukopis tvoří dvě sešité složky silného nazelenalého papíru prríčného formátu o šestnácti notových osnovách. První sešit $258 \times 333 \mathrm{~mm}$ má šest archů (12 folií, 24 s.), druhý sešit $260 \times 330 \mathrm{~mm}$ má 5 archů ( 9 folií, u 5 . archu je odstřižena pravá polovina, 18 s.), celkem 21 folií a 42 stran. Papír na první a poslední straně je zažloutlý a zašpiněný, na posledním listu politý. Listy jsou zčásti na vnějším okraji uprostřed ohnuté ve tvaru kruhové úseče, v rozích ohmatané.

Popsány jsou všechny strany hnědočerným inkoustem. Notový text (partitura) je rukopis Františka Škroupa, krasopisný zpěvní text psala zjevně jiná ruka. Ze Škroupovy ruky jsou také změny v textu a v notách perem a tužkou a patrně také dirigentské poznámky tužkou.

Paginace zapsaná tužkou na spodním okraji uprostřed, na vnitřním a vnějším okraji je chybná. Na poslední straně v levém horním rohu tužkou 42.

\section{Poslání skladby}

Existence Škroupovy árie je známá. Josef Plavec se o ní zmiňuje v monografii o Škroupovi, nicméně od té doby jí nebyla věnována žádná pozornost. ${ }^{1}$ Vkládání árií z jiných oper a komponování alternativních árií do vlastních i cizích oper patřilo v 19. století $\mathrm{k}$ běžné divadelní praxi. Škroup jako kapelník Stavovského divadla dodával k provozovaným četným divadelním kusům různých žánrů hudební složku v rozsahu od jednotlivých čísel až ke kompletním

Tento příspěvek je výsledkem badatelské činnosti podpořené Grantovou agenturou České republiky, projekt registrační číslo 20-19382S. - Za kolegiální pomoc při vzniku článku děkuji Jiřímu K. Kroupovi, Wolfgangu Kühnholdovi, Jitce Ludvové, Anetě Peterové, Vlastě Reittererové a Hartmutu Schickovi.

1) Viz PLAVEC, Josef: František Škroup, Melantrich, Praha 1940, s. 333-334. 


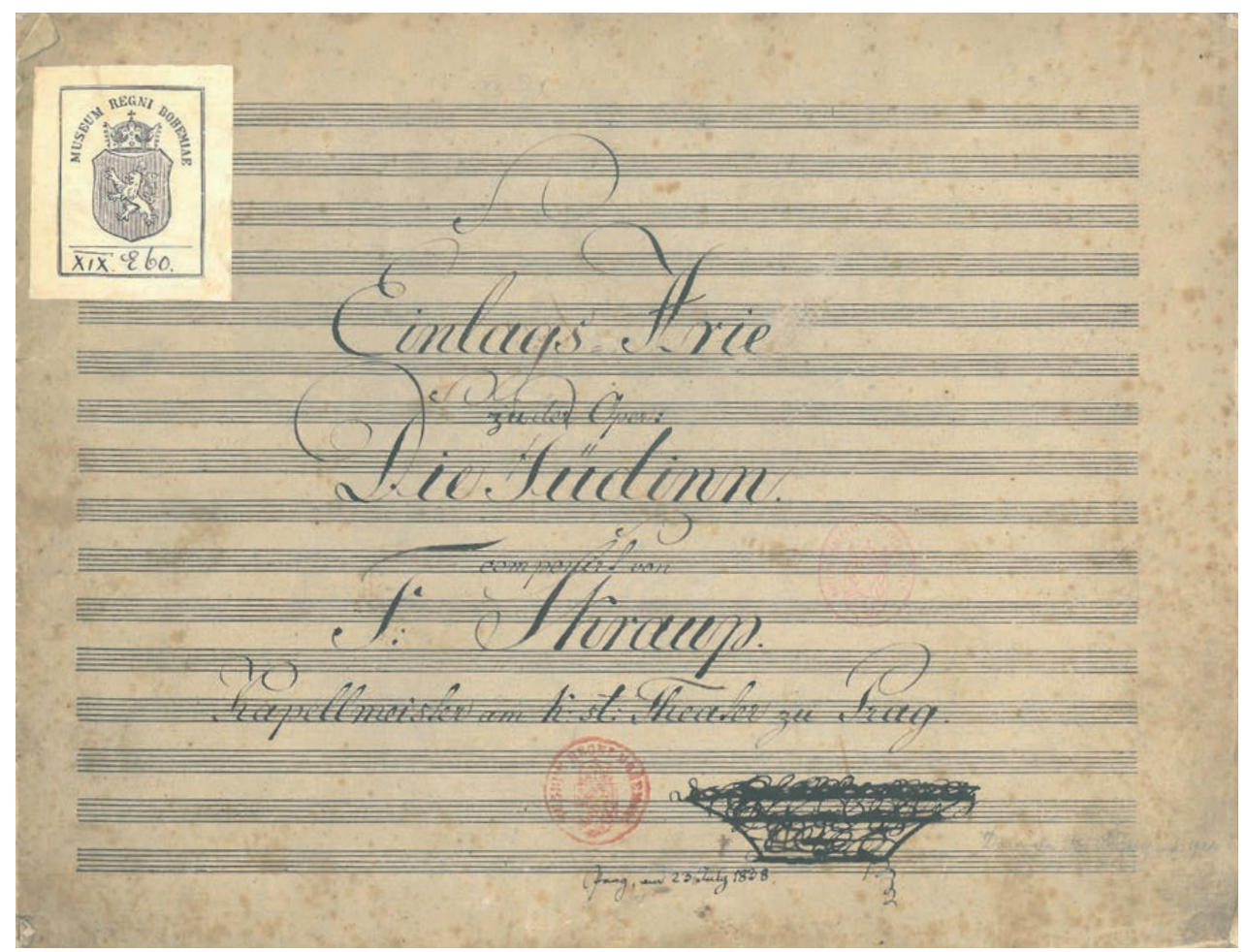

\section{František Škroup: Aria for the opera La Juive / Árie k opeře La Juive}

Autograph, score, p. 1, 1838 / Autograf, partitura, s. 1, 1838

NM-CMH XIXE 60

scénickým hudbám, ${ }^{2}$ avšak kompozice vložené árie je v jeho dosud známé tvorbě ojedinělá. Evidentně souvisí s prvním pražským provedením opery Fromentala Halévyho La Juive. Škroup ji nastudoval v němčině s názvem Die Jüdinn podle rakouské cenzurované verze Josepha Rittera von Seyfrieda a Georga Edlera von Hofmanna a uvedl v premiéře 25. července 1838. ${ }^{3}$ Árie patři do partu Eudoxie (v cenzurované verzi Isabella), byla tedy určena její

2) Ke Škroupovým kompozicím pro divadlo viz KABELKOVÁ, Markéta - LUDVOVÁ, Jitka: Škroup, František Jan [heslo], in: LUDVOVÁ, Jitka a kol.: Hudební divadlo v českých zemích, Divadelní ústav - Academia, Praha, 2006, s. 536-542 (dále LUDVOVÁ 2006), a in: Česká divadelní encyklopedie [online]. Dostupné z: http:// encyklopedie.idu.cz/index.php/\%C5\%AOkroup,_Franti\%C5\%Alek_Jan [cit. 26. 2. 2021].

3) K divadelní cenzuře v Rakousku a v českých zemích viz BACHLEITNER, Norbert: Die literarische Zensur in Österreich von 1751 bis 1848, Böhlau Verlag, Wien - Köln - Weimar 2017 (Literaturgeschichte in Studien und Quellen, Bd. 28) (dále BACHLEITNER); SCHERL, Adolf: $K$ nejstarším dějinám divadelní cenzury v Čechách, Divadelní revue, roč. 25, 2014, č. 1, s. 7-18; PÍŠA, Petr: Cenzura v Čechách v kontextu předbřeznové habsburské monarchie, disertační práce, Univerzita Karlova - Filozofická fakulta - Ústav českých dějin, [Praha] 2018. $\mathrm{K}$ cenzurované podobě opery La Juive ve Vídni a v Praze viz HEIDLBERGER, Franz: Halévys Jüdin in Wien. Zur Rezeptionsgeschichte einer Oper zwischen Zensur und Antisemitismus, in: Actes du colloque Fromental Halévy, eds. F. Claudon - G. de Van - K. Leich-Galland, Paris, Novembre 2000 (Etudes sur L'opéra français du XIXe siècle, vol. V), Musik-Edition Lucie Galland, Weinsberg 2003, s. 244-266 (dále CLAUDON), a POSPÍŠIL, Milan: Österreichische Opernzensur in Prag: Gustave III und La Juive, in: Eugène Scribe und das europäische Musiktheater (Forum Musiktheater, Bd. 6), ed. Sebastian Werr, LIT Verlag, Berlin 2007, s. 122-152. 
představitelce Kateřině Podhorské. ${ }^{4}$ Pro Podhorskou jako první zpěvačku pražského operního souboru bylo účinkování v novinkách francouzské grand opéra samozřejmou a prestižní záležitostí. Dosvědčuje to také skutečnost, že v ukázkách z nich se předváděla na koncertním pódiu už s předstihem před jejich pražskými divadelními premiérami. Z Halévyho opery přednesla 12. března 1838, několik měsíců před prvním provedením, s Henriettou Grosserovou duet Eudoxie a Rachel (v cenzurované verzi Sara) ze IV. jednání.

„Dvojzpèv z,Židovky' od Halévyho prednesly dámy Grosserová a Podhorská s vyznamenáním, ačkoli se málo hodí do koncertního sálu."

„Slečna Grosserová a paní Podhorská zpívaly velmi zdatně dvojzpěv z,Židovky, kterážto opera je Pražanum ještě neznámá."

Na témže koncertě Podhorská zpívala velkou scénu Marguerite č. 7 z II. jednání Meyerbeerovy opery Les Huguenots, která byla v cenzurované verzi jako Die Ghibellinen in Pisa ve Stavovském divadle uvedena až v roce 1840.

„[...] Pèvecký kus z,Hugenotư;, od Meyerbeera (poprvé), prednesený paní Podhorskou, paní Schumannovou, slečnou Balzerovou a Siegfriedem Rosenbergem, sopránů z nové izraelské modlitebny, patři bezesporu k nejobtižnějším pěveckým číslìm, která byla kdy napsána; ale třebaže paní Podhorská, která prevzala sólový hlas, vynaložila celé své umění, presto úspěch neodpovidal výkonu. Jak tento trojhlasnè doprovázený sólový zpěv, tak duet zopery,Židovka، od Halévyho (poprvé), prednesený slečnou Grosserovou a paní Podhorskou, opèt ohlásily, že se árie a duety ani z francouzské ani novějš́ nèmecké hudby na koncert nehodi."

Árii Marguerite Podhorská zopakovala ještě na koncertě, který pořádal houslista August Pott $^{7}$ ve Stavovském divadle 26. záŕí 1838:

4) Kateřina Podhorská, rozená Kometová (1807-1889), zpěvačka, patřila k nejlepším a nejoblíbenějším silám pražské opery. Viz LUDVOVÁ, Jitka: Podhorská, Kateřina [heslo], in: LUDVOVÁ 2006, op. cit. v pozn. 2, s. 408-411, a in: Česká divadelní encyklopedie [online]. Dostupné z: http://encyklopedie.idu.cz/index.php/ Podhorsk\%C3\%Al,_Kate\%C5\%99ina [cit. 26. 2. 2021]; Katharina Comet [heslo], in: Carl-Maria-von-WeberGesamtausgabe. Digitale Edition [online]. Dostupné z: http://weber-gesamtausgabe.de/A000B8D [cit. 26. 2. 2021]; Katharina Podhorský (geb. Comet) [heslo], in: Oesterreichisches Musiklexikon [online]. Dostupné z: https://www.musiklexikon.ac.at/ml?frames=no [cit. 26. 2. 2021].

5) „Ein Duett aus der ,Jüdin' von Halevy trugen die Damen Großer und Podhorsky mit Auszeichnung vor, obschon es sich wenig für den Concertsaal eignet." B.: Concert vom 5. März, Bohemia, roč. 11, 1838, č. 32 (16. 3.), s. [3]; „Dem. Großer und Mad. Podhorsky sangen recht wacker ein Duett ans der Jüdin', welche Oper den Pragern noch unbekannt ist." Dr. A.: Am 12. März fand in Prag [...], Allgemeine Theaterzeitung und Originalblatt für Kunst, Literatur, Musik und geselliges Leben, roč. 31, 1838, č. 67 (3. 4.), s. 296.

6) „[...] Ein Gesangstück aus den ,Hugenotten` von Meyerbeer (zum erstenmal), vorgetragen von Mad. Podhorsky, Mad. Schumann, Dem. Balzer und Siegfried Rosenberg, Sopranisten an dem neuen israel. Bethause, gehört unstreitig unter die schwierigsten Gesangsnummern, die je geschrieben wurden; aber wenn gleich Mad. Podhorsky, welche die Solostimme übernommen hatte, ihre ganze Kunst aufbot, so war doch der Erfolg nicht in Uebereinstimmung mit der Leistung, und sowohl dieser dreistimmig begleitete Sologesang, als das Duett aus der Oper ,Die Jüdin' von Halévy (zum erstenmal), vorgetragen von Dem. Grosser und Mad. Podhorsky, thaten aufs Neue die Wahrheit kund, dass die Arien und Duetten weder der französischen noch der neuern deutschen Musik sich für das Concert eignen." Nachrichten. Prag. (Schluss.), Allgemeine musikalische Zeitung, roč. 40, 1838, č. 16 (18. 4.), s. 258.

7) August Pott (1806-1883), německý houslista a skladatel. 
„Paní Podhorská prednesla na tomto koncertè brilantní árii od Meyerbeera tak výtečně, že ji publikum vyznamenalo stejným potleskem, jakého se dostalo pořadateli koncertu."

Z hlediska hlasových typů hlavních ženských rolí Halévy uplatnil konstelaci obdobnou jako před ním Meyerbeer v opeře Robert le diable. Úlohy Alice a Isabelly jsou psány pro takové zpěvačky prvního oboru, u nichž se podle vyjádření Eduarda Hanslicka předpokládalo, že spojují „brilantní pěveckou techniku s patetickým prédnesem recitativu a vášnivým výrazem silných pohnutých situaci", i když se v nich projevuje počátek pozdèjšího rozdělování sopránových rolí na "dramatické" a „,koloraturní“ „Meyerbeer už dèlí primadony na ty, kteréovládaji virtuozitu koloraturního zpěvu, a takové, které ji postrádaji. Verdi a úplně Richard Wagner znaji užjen zpěvačky jednoho druhu: ,dramatické, to znamená takové, jež koloraturního zpěvu nejsou mocny a z maestrovy milosti ho ani nepotřebuji."P Přesto není u Meyerbeera takové dèlení bezvýhradné. Dokládá to ostatně př́ímo repertoár zpěvaček v pařǐžské Académie royale de musique. O premiéŕe opery Robert le diable (1831) vytvořila Alici, tedy dramatickou roli, Julie Dorus-Gras ${ }^{10}$, a koloraturní Isabellu Laura Cinti-Damoreau. ${ }^{11}$ Avšak již v př́štím roce Dorus-Gras zpívala Isabellu. ${ }^{12}$ Po přestoupení Cinti-Damoreau do divadla Opéra-Comique převzala Dorus-Gras úplně její obor. V premiéré Les Huguenots (1836) jí Meyerbeer svěřil koloraturní úlohu královny Marguerite. Škálu schopností univerzální primadony manifestovala Dorus-Gras v benefičním přestavení př̀i odchodu ze své domovské scény (1845) právě na Meyerbeerovi: v prvním jednání Roberta představovala Alici a ve druhém Isabellu. ${ }^{13}$ V jistém smyslu vidíme podobné rozkročení mezi dvojicí ženských hrdinek velké opery také ve volbě rolí Kateřiny Podhorské, která jistě odpovídala shora uvedené Hanslickově definici operní primadony: „Jeji repertoár vykazoval takovou rozmanitost, že se nevědělo, jestli se má klasifikovat jako dramatická, koloraturní nebo mezzosopránová zpěvačka. ${ }^{\text {"94 }} \mathrm{V}$ pražské

8) „Mad. Podhorsky trug bei diesem Concerte eine brillante Arie von Meyerbeer so ausgezeichnet vor, daß sie das Publikum mit demselben Beifalle, welcher dem Concertgeber zu Theil wurde, hervorrief." MÜLLER, Anton: Kunst und Leben in Böhmen. Theaterbericht vom 19. bis 26. September, Bohemia, roč. 11, 1838, č. 116 (28. 9.), s. [4]. 9) „[...] [eine Sängerin, welche] eine brillante Gesangstechnik mit pathetischem Vortrag des Recitativs und leidenschaftlichem Ausdruck starker bewegter Situationen vereinigte [...] Meyerbeer theilt die Primadonnen schon in solche, welche Virtuosität im colorirten Gesang besitzen, und solche, denen sie fehlt. Verdi und vollends Richard Wagner kennen nur mehre Eine Gattung Sängerinnen: ,dramatische', das heißt solche, die des colorirten Gesanges nicht mächtig sind und dessen von Maestros Gnaden auch nicht bedürfen." HANSLICK, Eduard: Mozart, in: HANSLICK, Eduard: Die moderne Oper. Kritiken und Studien, A. Hofmann \& Co., Berlin 1875, s. 29-60, zde s. 53.

10) Julie Dorus-Gras (1805-1896), belgická sopranistka.

11) Laure Cinti-Damoreau (1801-1863), francouzská zpěvačka a skladatelka.

12) Dorus-Gras narychlo zaskočila za Cinti-Damoreau, která odmítla vystoupit se začátečnicí Marií-Cornelií Falcon. Debutem v roli Alice se zrodila tato hvězda pařížské opery - pozdější Halévyho Rachel a Meyerbeerova Valentine. Viz GHEUSI, Jacques - PAZDRO, Michel - RAVIER, Dominique: L'œuvre à l'affiche, L'Avant scène. Opéra, opérette 1985, č. 76, červen, s. 102-106.

13) Viz WHITE, Kimberly: Female Singers on the French Stage, 1830-1848, Cambridge University Press, Cambridge 2018, s. 121.

14) „Ihr Repertoire wies eine derartige Mannigfaltigkeit auf, daß man nicht wußte, sollte man sie als dramatische-, Coloratur- oder Mezzosopransängerin classificiren." TEUBER, Oscar: Geschichte des Prager Theaters. Von den Anfängen des Schauspielwesens bis auf die neueste Zeit. III., A. Haase, Prag 1888, s. 268 (dále TEUBER). 
premiéře Robert der Teufel ztělesnila Alici Podhorská a Isabellu Jenny Lutzerová (které si mimochodem velmi vážil Meyerbeer). ${ }^{15}$ Později převzala Podhorská Isabellu, zatímco Alici představovala Henriette Grosserová. Obdobně se obě zpěvačky podělily o dramatickou úlohu Rachel/Sary a koloraturní Eudoxii/Isabellu v La Juive. ${ }^{16}$

Položme si otázku, proč se měla role Eudoxie obohatit ne snad alternativní, ale vloženou árií? Důvod ležel nasnadě: v Halévyho opeře, jak ji podávala autorizovaná tištěná partitura, Eudoxie žádnou árii neměla. ${ }^{17}$ Bylo tomu tak proto, že Halévy podobně jako Meyerbeer byl kvůli přílišné délce nucen po premiéře (1835) své dílo zkrátit. Proto mj. vypustil celý první obraz III. jednání, kde právě Eudoxie měla dokonce několik sólových čísel: č. 13 árii, č. 14 duet s Rachel a č. 15 bolero. Dotyčná čísla sice obsahoval klavírní výtah, ale partitura ne. ${ }^{18}$ Role Eudoxie byla tímto zásahem samozřejmě poškozena z hlediska své hudební závažnosti a stala se pro koloraturní sopranistku méně vděčnou.

\section{Text a hudba árie}

Hrdinka Scriba a Halévyho, údajná židovka Rachel, je ve skutečnosti křest’anská dívka. Na její utajené dvojí totožnosti je postaven příběh opery. Předpoklady děje zasazeného do Kostnice v době církevního koncilu na počátku 15. století spočívají v dávné minulosti. Kardinál Brogni kdysi žil v Římě jako světský člověk, měl ženu a dceru. Když o obě přišel za útoku neapolského vojska, vydal se na církevní dráhu. Nedověděl se, že jeho dceru s nasazením vlastního života z hořícího domu zachránil Žid Éléazar. Oba muži se po létech setkávají v Kostnici. Konflikt dvou otců jedné dcery, reprezentantů nesmiřitelných náboženství, jednoho utiskovaného a druhého utiskujícího, je předveden s krajní vystupňovaností dramatických situací. Zvítězí odpuštění, prozradí Žid Éléazar tajemství adoptivní dcery, nebo z ní učiní nástroj pomsty na křestanech za utrpěná příkoří svého národa tím, že ji vydá na smrt před očima jejího vlastního otce? Před tuto volbu ho postaví sama Rachel. Zamilovala se do údajného židovského malîre Samuela. Pod falešnou totožností se ukrývá císařský vojevůdce Léopold, manžel princezny Eudoxie. Rachel odhalí jeho podvod a veřejně ho obviní, že udržoval styk s židovkou.

15) Srov. Meyerbeerovo vyjádření „, meine unvergeßliche Isabelle und Margarethe" $v$ dopise Franzi svobodnému pánu von Dingelstedt, manželovi Lutzerové, z 28. června 1860. Viz BECKER, Heinz und Gudrun: Giacomo Meyerbeer. Ein Leben in Briefen, Heinrichshofen, Wilhelmshaven 1983, s. 226-227, zde s. 227.

16) Protože v létě 1838 byla Henriette Grosserová na umělecké cestě, zastoupila ji v prvních šesti představeních Josepha Eschenová. Od 9. záŕí 1838 ji natrvalo vystřídala Grosserová.

17) Viz HALÉVY, Fromental: La Juive. Opéra en cinq actes. Paroles de Mr E. Scribe. Musique de [...] Partition. Maurice Schlesinger, Paris [s. a. = 1836]. - III. jednání začíná až scénou v císařských zahradách č. 13 Chœur „Ô jour mémorable[,] ô jour de splendeur", s. 367. První obraz byl vypuštěn i ve vydání libreta. Viz SCRIBE, Eugène: La Juive. Opéra en cinq actes, [...] Musique de M. Halévy, in: SCRIBE, Eugène: Théâtre complet de M. Eugène Scribe, [...] 14, Aimé André, Paris 1835, s. 389-459 (dále SCRIBE). - Ke škrtům v partituře viz LEICH-GALLAND, Karl: Formes changeantes de La Juive, in: Le Retour de Rachel. Actes du colloque organisé à l'occasion de la reprise de La Juive à l'Opéra de Paris en février 2007, ed. Karl Leich-Galland, Musik-Edition Lucie Galland, Weinsberg 2013, s. [152]-159 (dále LEICH-GALLAND).

18) Proto se také neshoduje označení čísel v klavírním výtahu a v partituře. První obraz III. jednání poskytla interpretům až v nejnovější době kritická edice. Viz HALÉVY, Fromental: La Juive. Opera in five acts. Text by Eugène Scribe; edited by Karl Leich-Galland (New edition of selected operas / Fromental Halévy), AlkorEdition, Kassel - Lucie Galland, Weinsberg 2005. 
Léopold, Rachel i Éléazar jsou uvrženi do klatby a hrozí jim trest smrti. Podvedená Eudoxie nevěrného manžela stále miluje. Uprosí Rachel, aby své obvinění popřela a tím Léopolda zachránila. Rachel a Éléazar odmítnou přijmout křest a jsou odhodláni zemřít. Dav volající po pogromu na Židy změní Éléazarovo odhodlání zachránit Rachel a přivede ho k rozhodnutí pomstít se křestanům v osobě jejich nejvyššího představitele: kardinál Brogni se teprve v okamžiku popravy Rachel od Éléazara dovídá, že odsoudil k smrti vlastní dceru.

Ze scén, v nichž vystupuje Eudoxie, přicházelo v úvahu jediné místo, kam by se dala árie pro ni umístit, a to první výstup IV. jednání. Eudoxie si vyžádala od kardinála Brogniho svolení k rozmluvě s uvězněnou Rachel. Očekává její příchod připravena vyprosit si na ní záchranu svého manžela Léopolda. Pro árii, v níž by postava vyzpívala své vnitřní rozpoložení, je to př́íhodná situace. Autor textu árie je neznámý. Snad to byl některý z literárně činných členů Stavovského divadla, kteří se Škroupem spolupracovali, jako Jan Nepomuk Štěpánek, František Valentin Ernst nebo Carl Joseph Schikaneder. ${ }^{19}$

Pro představu o pražském dodatku porovnejme znění textu prvního výstupu z tisků libret Scriba, německé verze Seyfrieda a Hofmanna a z rukopisné Škroupovy partitury ${ }^{20}$ :

\author{
Scribe \\ Acte IV. \\ Un appartement gothique qui \\ précède la chambre du concile. \\ Scène première.
}

Eudoxie, et plusieurs gardes à qui elle présente un papier.

Du prince de Brogni voici

l'ordre suprême.

Il me permet de voir Rachel

quelques instants.

(Les gardes sortent par la porte à droite.)

Mon Dieu! pour délivrer l'infidèle que

j'aime,

Viens soutenir ma voix et dicter mes accents.

Que je sauve ses jours! et puis qu'après je meure!

\author{
Seyfried \& Hofmann \\ Vierter Aufzug. \\ Gotisches Gemach vor der \\ Gerichtshalle. \\ Erste Scene.
}

Isabella. Mehrere Wächter.

Isabella (zu den Wächtern).

Ihr seht hier die Befehle des

Comthurs;

Die hier gefangen ist, erlaubt er mir zu sehen.

(Die Wächter entfernen sich rechts.)

Den Falschen zu befrei'n, den ich im Herzen Den falschen zu befrein, den ich im Herzen trage,

Gib meiner Schwäche Muth, gib meiner

Zunge Kraft.

Ist frei er, mag sich mein Geschick entscheiden.
(Nezjištěný autor)

Isabella

Ihr sehet hier den Befehl des Eomthurs

Cardinals[.]

Die hier gefangen ist[]] erlaubt er mir zu sehn!

trage!

gieb meiner Schwäche Muth[,] meinen

Worten Kraft!

Rett ich ihn vor Gefahr[,] mag mein

Geschick sich entscheiden!

19) Viz KUSÁKOVÁ, Lenka - LUDVOVÁ, Jitka: Štěpánek, Jan Nepomuk [heslo], in: Česká divadelní encyklopedie [online]. Dostupné z: http://encyklopedie.idu.cz/index.php/\%C5\%AOt\%C4\%9Bp\%C3\%Alnek,_Jan_ Nepomuk [cit. 6. 3. 2021]; SCHERL, Adolf: Schikaneder, Carl Joseph [heslo], in: tamtéž, http://encyklopedie.idu. cz/index.php/Schikaneder,_Carl_Joseph [cit. 6. 3. 2021]; LUDVOVÁ, Jitka: Ernst, Ferdinand Valentin [heslo], in: tamtéž, http://encyklopedie.idu.cz/index.php/Ernst,_Ferdinand_Valentin [cit. 6. 3. 2021].

20) Text je rekonstruován do pravděpodobné podoby vložky do libreta, tj. reprodukuje se bez opakování veršů a slov a dalších zásahů vyplývajících ze zhudebnění. Ke změnám jmen jednajících osob viz dále část o provozování árie. 
Als für Sara Recha er erglühte!

und dieß treue Herz verstieß[,]

welkte meiner Liebe Blüthe

sank dahin mein Paradieß!

Wüßte er[,] wie ich gerungen,

sicher trübte sich sein Blick,

doch mein Herz hab ich bezwungen,

neu erblühen soll sein Glück.

Darf ich jetzt auch mein ihn nicht mehr

nennen,

eil ich doch zur Rettung froh herbei!

und in Saras Rechas Arm soll er erkennen,

daß dieß Herz inn liebte wahr und treu!

Sey beglückt[,] Geliebter[,] ich entsage

deiner Liebe! ich will einsam stehn!

meiner Brust entschlüpfet keine Klage[,]

werd ich dich nur froh und glücklich sehn!

V textu árie Isabella teskní nad tím, že Arnauld/Léopold ji už nemiluje. Ona mu svou lásku dokáže tím, že mu dá volnost. Předpoklad takového rozhodování byl dán tím, že na rozdíl od Scriba, kde Léopold je manželem Eudoxie, jsou v cenzurní verzi Arnauld a Isabella jen snoubenci. Předvádět skutečnou manželskou nevěru na jevišti nebylo v Rakousku př́pustné. ${ }^{21}$ Isabella může Arnaulda zachránit jen tak, že prosbami obměkčí Saru, aby své obvinění odvolala a poměr s křest̉anem zapřela. To se v duetu Eudoxie/Isabelly a Rachel/Sary také stane. Zato Isabellin nesobecký cíl, vyjádřený árií, totiž aby nevěrný milenec spočinul v náručí sokyně, je z hlediska fabule libreta nemyslitelný až absurdní. Vždyt̉ za milostný vztah křestana a židovky tu oběma hrozí trest smrti. Takové vykolejení z dějové kauzality představuje exces nejen ve vztahu ke Scribovi, ale i k německým libretistům Seyfriedu - Hofmannovi. Text vložené árie byl koncipován v rámci téměř idylického prožívání štastné a neštastné lásky s úplným opominutím dramatického kontextu asi proto, aby rychlá věta mohla árii zakončit radostně. Jásot nad spasením milovaného člověka za cenu obětování vlastního života není v opeře ničím neobvyklým. Přitom ve Scribově originálu je taková perspektiva slovy Eudoxie jasně vyjádřena: „Kéž zachráním jeho život! A potom at’ zemřu!"22 Eudoxie očekává smrt i potom, co dosáhne svého záměru osvobodit Léopolda. S Rachel se loučí slovy: „Stejně jako tobě, Rachel, jak doufám, smrt brzy ukonči mé trápení... "23 Předvádění a reflexe sebevraždy na jevišti podléhaly v Rakousku přísnému cenzurnímu dohledu, ${ }^{24}$ a proto i jen narážkám na ni se Seyfried a Hofmann úplně vyhnuli. V cenzurně konformní verzi je pouhá

21) Srov. všeobecné směrnice pro cenzuru, jak byly formulovány v pamětním spise vládního rady Franze Karla Hägelina z roku 1795 pro divadelní cenzuru v Uhrách a které se uplatňovaly až do roku 1848. Jsou vydány in GLOSSY, Carl: Zur Geschichte der Wiener Theatercensur, in: Jahrbuch der Grillparzer-Gesellschaft, roč. 7, 1897, s. 238-340 (dále GLOSSY). Viz zejména oddíl „Gebrechen des Stoffes in Absicht auf die Sitten“, s. 317-320. Nově přetištěny in BACHLEITNER, op. cit. v pozn. 3, s. 438-462.

22) „Que je sauve ses jours! et puis qu’après je meure!" SCRIBE, op. cit. v pozn. 17, s. [439].

23) „Ainsi que toi, Rachel, le trépas, je l'espère, || Aura bientôt terminé ma misère..." SCRIBE, op. cit. v pozn. 17, s. 443.

24) Viz GLOSSY, op. cit. v pozn. 21, s. 315, 323-324; BACHLEITNER, op. cit. v pozn. 3, s. 447-448, 452-453. 
myšlenka na ukončení života vyloučena: „Až bude volný, at’ se rozhodne můj osud.'25 A tento osud Isabella spatřuje v odchodu do kláštera: „Mne at’ uzavře temná kobka; to je správné misto pro choré srdce. ${ }^{\text {26 }}$

Nepravidelně veršovaný začátek je zjevně určený ke zhudebnění jako recitativ (Ja selbst das schwerste will ich dulden [...] Doch muß es sein). Verše vlastní árie se dělí do dvou částí. Dvě čtyřverší jsou ve čtyřstopém a dvě čtyřverší v pětistopém trocheji, všechna se stř́idavými rýmy. Otevřený vokál [a] (ve výslovnosti) v mužských nečistých rýmech s dvojhláskami ei [aI], eu [oỹ] „herbei, treu“"v první pětistopé strofě a dlouhý otevřený vokál [a:] v předposlední stopě jejího čtvrtého verše „wahr und treu“ se viditelně nabízejí k tomu, aby dotyčná jednoslabičná slova mohla být výhodně podložena koloraturním pasážím, případně v závěru árie obvyklým vysokým tónům tóniky nebo dominanty.

Škroup si bezpochyby vyžádal text uspořádaný tak, aby ho mohl zhudebnit ve formě dvouvěté árie s pomalou (recitativo, adagio) a rychlou větou (cabaletta). ${ }^{27}$ Dvouvětá árie byla tehdy pevně spjatá s představou velkého pěveckého čísla, které skladatelé nasazovali zpravidla ve vypjatých dramatických situacích. Árie je začleněna v partituře La Juive do čísla 16 Scène et duo. Ve Škroupově autografu je na první straně not bez názvu a označena číslem 13, což vypovídá o tom, že v pražské verzi bylo několik čísel vynecháno. Začátek skladby převzal Škroup z Halévyho, ale s dílčími změnami v textu Seyfrieda a Hofmanna i ve zpěvní lince německého recitativu, až do konce taktu 26. Odtud začíná vlastní kompozice vložky ve formě dvouvěté árie s částmi recitativ (takty 27-42) a pomalá věta ve strofické dvoudílné formě (43-81), která bez spojovací části tempo di mezzo přechází do rychlé věty (82-186). Rychlá věta nemá standardní stavbu italské cabaletty doslovně se opakující po krátké mezivětě, ale je podle obvyklého způsobu francouzské a německé opery utvářena v třídílné formě $\mathrm{s}$ reprízou a kódou, ${ }^{28}$ kterou Škroup uplatňuje i ve vlastních operách (např. v áriích Libuše v Libušině sňatku nebo Marie v Columbovi). ${ }^{29}$ Návrat do Halévyho kompozice se uskutečňuje dvěma takty chromatické modulace z hlavní tóniny árie E dur do As dur.

25) „Ist frei er, mag sich mein Geschick entscheiden." SEYFRIED, Ignaz Ritter von - HOFMANN, Georg von: Die Jüdinn. Große Oper in fünf Aufzügen, mit Divertissement. Nach dem Französischen des Scribe, von [...] Musik von Halevy. J. B. Wallishausser, Wien 1836, s. [43] (dále SEYFRIED - HOFMANN).

26) „Mich umschließe eine düst're Zelle; || Ein krankes Herz hat dort die rechte Stelle." SEYFRIED HOFMANN, op. cit. v pozn. 25 , s. 46.

27) DÖHRING, Sieghart: Formgeschichte der Opernarie vom Ausgang des achtzehnten bis zur Mitte des neunzehnten Jahrhunderts, George, Itzehoe 1975 (dále DÖHRING). - K charakteristice dvouvěté árie a jejích částí viz JOERG, Guido Johannes: Glossar, in: Verdi Handbuch, eds. Anselm Gerhard - Uwe Schweikert, Metzler Bärenreiter, Stuttgart - Weimar 2013, s. 698-716.

28) $\mathrm{K}$ formě dvouvěté árie ve francouzské opeře a německé opeře viz DÖHRING, op. cit. v pozn. 27 a SCHNEIDER, Herbert: Les airs vocaux des opéras d'Halévy, in: CLAUDON, op. cit. v pozn. 3, s. 169-192; SCHNEIDER, Herbert: Cavatine, Cantabile und Cabaletta in den Opéras-comique von Scribe, Auber und einigen ihrer Zeitgenossen, in: Musiktheater im Fokus, eds. Sieghart Döhring - Stefanie Rauch, Studio Verlag, Sinzig 2014, s. 497-518.

29) Viz ŠKROUP, František: Libušin sňatek, III. jednání, č. 16. Arie; Columbus, III. jednání, č. 19. Recitativo; Columbus, III. jednání, č. 19. Recitativo \& Aria con Coro. 
Milan Pospišil

Schéma formy:

\begin{tabular}{|c|c|c|c|c|c|c|}
\hline Autor & Část & & Takt & Metrum a tempo & Tónina & Textový incipit \\
\hline Halévy & & & $1-26$ & C, Moderato & $g$ & Ihr sehet hier den Befehl \\
\hline \multirow[t]{10}{*}{ Škroup } & Recitativ & & $27-42$ & Recit $^{\text {vo }}$ & $\mathrm{h} \rightarrow \mathrm{E}$ & Ja selbst das schwerste \\
\hline & $\begin{array}{l}\text { Pomalá } \\
\text { věta }\end{array}$ & $\mathrm{a}$ & $43-55$ & 2/4, And ${ }^{\text {te }}$ & $\mathrm{E} \rightarrow \mathrm{H}$ & $\begin{array}{l}\text { Als für Sara er erglühte! } \\
\text { (notový incipit př́klad 1) }\end{array}$ \\
\hline & & b & $55-63$ & & $\mathrm{H}$ & Wüßte er, wie ich gerungen \\
\hline & & $\mathrm{a}$ & $63-73$ & & $\mathrm{E} \rightarrow \mathrm{H}$ & Als für Sara er erglühte! \\
\hline & & $b^{\prime}$ & $73-81$ & & $\mathrm{H}$ & Wüßte er, wie ich gerungen \\
\hline & $\begin{array}{l}\text { Rychlá } \\
\text { věta }\end{array}$ & c & $82-98$ & C, Allo: & $\mathrm{E} \rightarrow \mathrm{Fis}$ & $\begin{array}{l}\text { Darf ich jetzt auch mein ihn nicht } \\
\text { mehr nennen (notový incipit } \\
\text { přiklad 2) }\end{array}$ \\
\hline & & $d$ & $98-130$ & & $\mathrm{H}$ & Sei beglückt Geliebter \\
\hline & & c & $131-149$ & & $E$ & $\begin{array}{l}\text { Darf ich jetzt auch mein ihn nicht } \\
\text { mehr nennen }\end{array}$ \\
\hline & Koda & k & 149-186 & & E & daß dies Herz ihn liebte \\
\hline & Přechod & & 187-189 & Andante con moto & $\mathrm{E} \rightarrow \mathrm{As}$ & \\
\hline Halévy & & & $27=$ Š 189 & And $d^{\text {te }}$ con moto & As & \\
\hline
\end{tabular}

1.
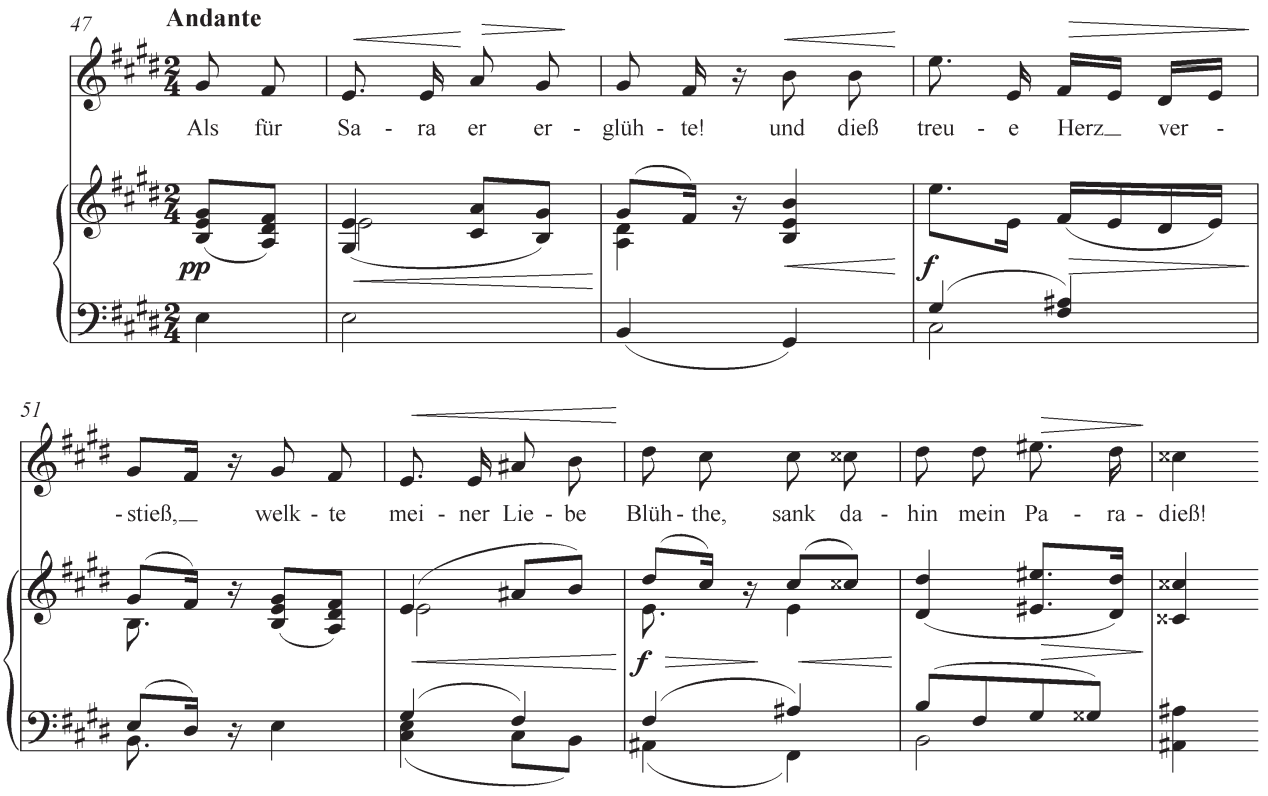
2.

82 Allegro
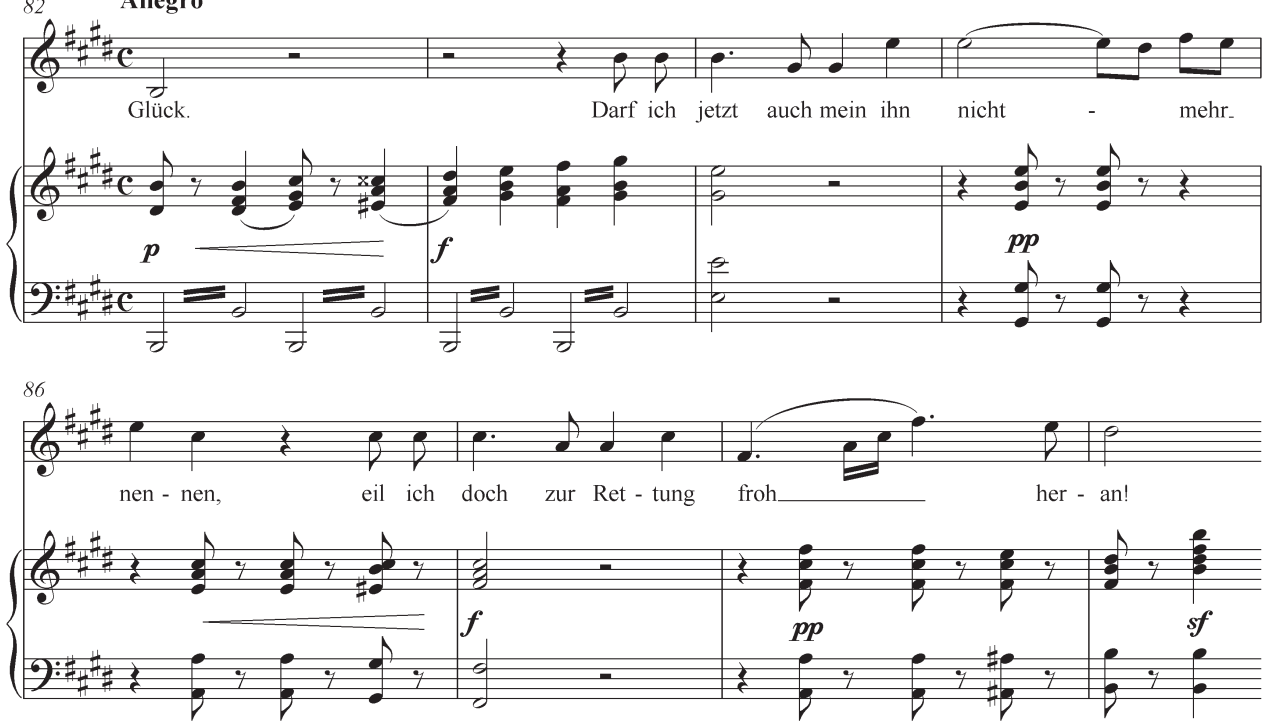

$\mathrm{V}$ árii napsané pro určitou představitelku nás může zajímat, zda vokální part obsahuje postupy, jimiž chtěl skladatel uplatnit některé přednosti jejího pěveckého umění. Vzhledem k pověsti Podhorské jako znamenité koloraturní zpěvačky to budou nejspíš místa, která vyžadují virtuozitu. Kritika u ní zvlášṫ obdivovala „nádherné trylky a elegantně provedené triolové pasáže “. ${ }^{30}$ Podle dobové paměti se v jejím zpěvu projevovala vzorová „přesnost, s niž uměla $i v$ těch nejmenších časových dílcích seřadit za sebou tóny jako na šňưre perel“. ${ }^{31}$ Koloraturou vybavil Škroup rychlou větu. Árie celou svou polohou odpovídá spíše mezzosopránu (h gis $^{2}$ ), ale v kódě stoupá rozsah do výšky až k cis ${ }^{3}$. Uplatňují se tu trylky, efektní triolové pasáže a chromatická sestupná škála přes dvě oktávy:

30) „In diesem zweiten Akte [Héroldova opera Ludovic dokončená Halévym] sprach eine einzige Arie, die Mad. Podhorsky sang, durch ihren herrlichen Triller und die elegant ausgeführten Triolenpassagen an, aber diese Arie war aus Auber's ,Lestocq' eingelegt." Nachrichten. Prag, Allgemeine musikalische Zeitung, roč. 40, 1838, č. 14 (4. 4.), sloupec 221-225, zde 224.

31) „Was an ihrem Gelang musterhaft genannt werden mußte, war die Accuratesse, mit welcher sie selbst in den kleinsten Zeittheilchen die Töne wie an einer Perlenschnur an einander zu reihen verstand, [...]" TEUBER, op. cit. v pozn. 14, s. 176. 
Milan Pospissil

3.

156 tronnminnminninin

$Q_{0}$

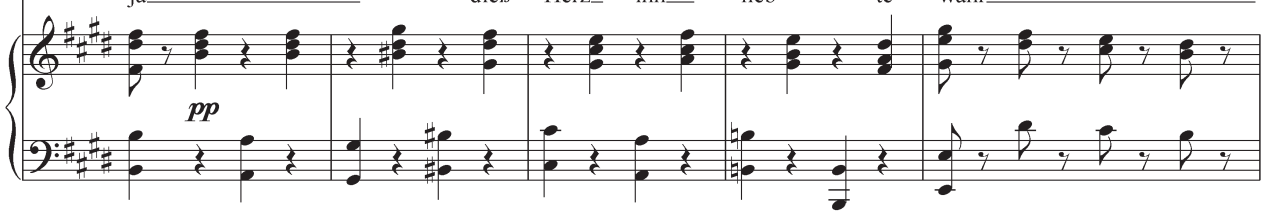

6

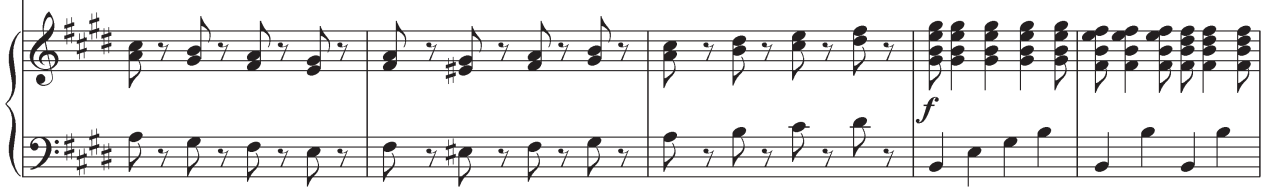

$6_{\frac{1}{3}}^{166}$

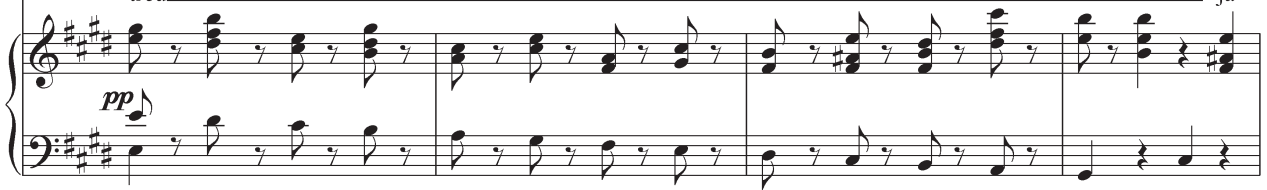

$\oint_{\text {wahr }}^{170}$

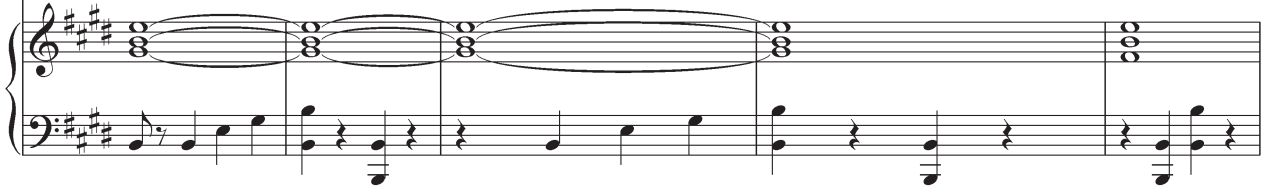

$Q_{0}^{175}$

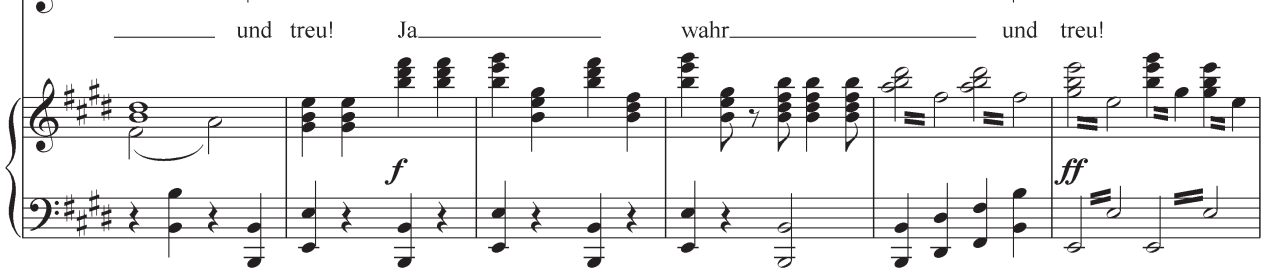




\section{Provozování}

Kateřina Podhorská vkládala do svých rolí árie z jiných oper a vložené cizí árie zpívala i na koncertech. Např. v Bö̈eldieuově opeře Les Deux nuits zpívala jakousi italskou árii:

„Bouřlivý potlesk večera obdržela jedna - italská árie, kterou paní Podhorská vložila ve druhém jednání a která se na francouzském základě vyjímala velmi zvláštně a cizorodě.32

Do Adamovy opery Le Fidèle berger zase vložila árii z Halévyho opery Guido et Ginevra, ou La Peste de Florence:

„Mimo jeden sbor rybářu v prvním jednání a jednu kavatinu, vloženou paní Podhorskou a vyňatou z Moru ve Florencii od Halévyho, žádné číslo nebylo aplaudováno a opera začala a skončila $v$ tichu. ${ }^{\text {‘3 }}$

Lze proto předpokládat, že Škroup árii pro ni složil možná i na její přání. Na kompozici árie zřejmě pomýšlel od rozhodnutí operu nastudovat. V každém případě musel být text árie už obsažen v rukopise libreta předloženém k cenzurnímu schválení v červnu $1838 .^{34}$ Autograf partitury árie nese datum 23. července, tj. dva dny před premiérou. I při rychlosti tehdejšího studování se přesto nezdá pravděpodobné, že se počítalo s jejím provedením už při premiéře. Divadelní cedule na ni na rozdíl od tehdejších zvyklostí neupozorňují. Naopak se její nepř́slušnost k Halévyho skladbě asi měla před obecenstvem skrýt. Z tisku vyplývá, že Podhorská vložku o premiéře ještě nezpívala, ale až při své benefici, pro kterou byla árie pravděpodobně od počátku určena. Představení ve prospěch Podhorské bylo původně ohlášeno na 27. července, avšak pro onemocnění představitelky Sary se konalo 3. srpna.

„Představení, benefice našeho prvního tenoristy Demmera, bylo hojně navštíveno, bohužel bylo jeho opakování kvůli nemoci slečny Eschenové prerušeno. 35

32) „Den stürmischsten Beifall des Abends erhielt eine - italienische Arie, welche Mad. Podhorsky im zweiten Akte eingelegt hatte und die sich auf dem französischen Grunde gar sonderbar und fremdartig ausnahm." Z. 17.: Prag (Beschluß), Allgemeine musikalische Zeitung, roč. 41, 1839, č. 49 (4. 12.), sloupec 986-987, zde 986. 33) „Tranne un coro di pescatori nel primo atto, e una cavatina introdotta per la signora Podhorsky e tolta dalla Peste di Firenze di Halevy, nessun pezzo fu applaudito, e l'opera incominciò e si chiuse nel silenzio. "Gazzetta teatrale e musicale. Praga, La Fama. Giornale di scienze, lettere, arti, industria e teatri, roč. 4, 1839, č. 37, (27. 3.), s. 148. 34) Viz Národní archiv Praha, fond Presidium českého gubernia, kniha 220 Censurirte Theaterstücke für die Prager Bühne 1838-1843 [nestránkováno]: „Nro. 31. Die Jüdin Große Oper in 5 Akt. mit Divertissement Nach dem Französischen des Scribe v Seyfried \& Hofmann. Musik von Halevy. dto. [=Manuskript] dto. [=Darf aufgeführt werden] Tag der Erledigung 18/6 [1838]“. Na protilehlé straně je poznamenáno tužkou: „Einlags Duett zur Jüdin: Sara P 4/p - 5/p darf aufgef werden 4 Sept. 838". - Snad šlo o to, že duet Isabelly a Sary byl v Praze nejprve zkrácený a Henriette Grosserová si ho přála zpívat tak, jako 31. července 1838 při svém hostování v Drážd'anech. S tím související rozšíření textu (možná i z překladu Carla Augusta svobodného pána von Lichtensteina nebo Friederike Ellmenreichové) ovšem vyžadovalo cenzurní schválení, což bylo uděleno pět dní před pražským vystoupením Grosserové v roli Rachel/Sary. Všechny úvahy jsou nicméně jen hypotézami, protože provozovací materiál Die Jüdin ze Stavovského divadla této doby se nezachoval.

35) „Die Vorstellung, das Benefize unseres ersten Tenoristen Demmer, war zahlreich besucht, leider wurde die Wiederholung derselben durch die Krankheit der Dem. Eschen unterbrochen." MARENGO: Prager Zustände. (Schluß.), Allgemeine Theaterzeitung und Originalblatt für Kunst, Literatur, Musik und geselliges Leben, roč. 31,1838 , č. 172 (28. 8.), s. 767. 
Provedení árie v benefici Podhorské dosvědčuje pražský dopisovatel listu Wiener Zeitschrift für Kunst, Literatur, Theater und Mode, a navíc se pozastavuje nad tím, že to zdejší referent vůbec nezaznamenal. Tím také výslovně dokládá, že recenze benefičního představení od Antona Müllera v Bohemii není se zřetelem k vložené árii spolehlivá:

„Dost zvláštni bylo, že při druhém představeni Halévyho ,Židovky' predehru nahradil jenom hudebni úvod. Naproti tomu pan Demmer zpival ve třetím dějstvi ${ }^{36}$ velkou árii Eleazara, kterou poprvé vynechal. (Také paní Podhorská vložila pěknou, ale zcela cizorodou árii.). Mistní korespondent, který referoval o obou produkcích a neuvédomil si ani toto plus ani ono minus, míní pouze: ,(neprovedená) predehra prošla, stejně jako v prvním představení, bez značnějšího zájmu publika."'37

Referentu lipského časopisu Allgemeine musikalische Zeitung, zjevně dobře obeznámenému s hodnoceným dílem, ovšem zvláštnosti pražského provedení neušly.

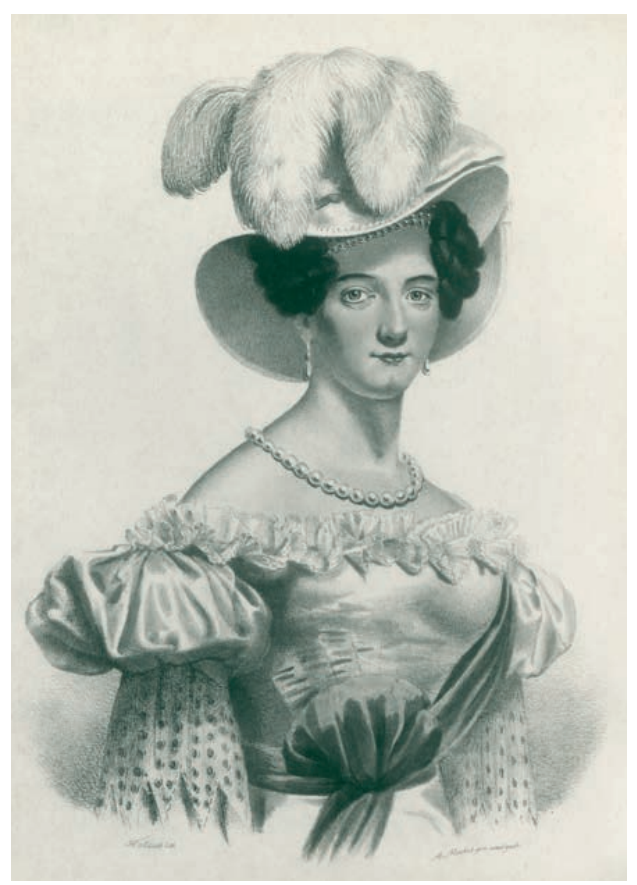

Kateřina Podhorská Kometová (1807-1889) Lithograph by $\mathrm{H}$. Schödl based on an original by Antonín Machek, in the role of Sophie in the opera Sargines by Ferdinando Paër / Litografie, H. Schödl podle předlohy Antonína Machka, v roli Žofie $\checkmark$ opeře Sargines od Ferdinanda Paëra NM-MBS E XIV.b/75

\begin{abstract}
„Pani Podhorská (Isabella) vytvořila ze své dosti nevděčné role, co se jen dalo udělat; její árie ve čtvrtém jednání byla zkrácena až knepoznání (jako vůbec celá opera byla nepochopitelným a neomluvitelným zpưsobem seškrtána), a v reprízách vložila jednu árii, která zcela jistě není od Halévyho. Zdá se, že jejím základem je mozartovský motiv, provedený moderním italským zpưsobem."38
\end{abstract}

\title{
36) Správně „ve čtvrtém".
}

37) „Sonderbar genug wurde bey der zweyten Vorstellung von Halevy's, Jüdin' statt der Ouvertüre nur eine musikalische Introduction substituirt, dagegen sang Hr. Demmer die große Arie des Eleazar im dritten Acte, die er das erste Mal ausgelassen hatte. (Auch Mad. Podhorsky hatte eine hübsche, aber ganz fremdartige Arie eingelegt.) Ein hiesiger Berichterstatter, der über beyde Productionen referirte, und weder dies plus noch jenes minus inne geworden war, meint bloß: , die (nicht aufgeführte) Ouvertüre ging, wie bey der ersten Vorstellung, ohne bedeutende Theilnahme des Publicums vorüber." Correspondenz-Nachrichten. Prag, im August 1838. (Schluß.), Wiener Zeitschrift für Kunst, Literatur, Theater und Mode [ročník neuveden], 1838, č. 107 (6. 9.), s. 854. - Srov. „Die Ouvertüre ging wie bei der ersten Vorstellung ohne bedeutende Theilnahme des Publicums vorüber." [MÜLLER, Anton]: Theater und geselliges Leben. Theaterbericht vom 3. August, Bohemia, roč. 15, 1838, č. 93 (5. 8.), s. [3]-[4], zde s. [3].

38) „Mad. Podhorsky (Isabella) machte aus ihrer ziemlich undankbaren Partie, was nur immer daraus zu gestalten ist; ihre Arie im vierten Akte war bis zur Unkenntlichkeit gekürzt (wie überhaupt die ganze Oper 
Můžeme se domnívat, že árie zůstala součástí představení Die Jüdin ve Stavovském divadle. Změny zpěvního hlasu a různé opravy a retuše v orchestrálním partu si bezpochyby vyžádala provozovací praxe. Nehledě k viditelnému opotřebení partitury, které svědčí o jejím častějǐím používání.

Máme také jednu zprávu o tom, že Podhorská zpívala árii na koncertě ve prospěch Ústavu pro zaopatřování a zaměstnání dospělých slepců v Praze 26. února 1842:

„Píseň ,Do dálky' citlivě prokomponovanou od J. N. Škroupa, a árii od Františka Škroupa, složenou jako vložku do Halévyho ,Židovky, prednesli pan Strakatý a paní Podhorská za hlučného potlesku; [...] ] $]^{\text {s9 }}$

Není známo, jestli provozování Škroupovy árie přesáhlo pražské prostředí. Při prvním uvedení Die Jüdin v Mnichově 18 . dubna 1844 byla údajně do opery vložena árie pro Eudoxii/Isabellu „napsaná cizí rukou“.40 Isabellu tam zpívala někdejší členka a později host Stavovského divadla Jindřiška Rettigová (Henriette Rettich). ${ }^{41}$ Při neznalosti podrobností nelze spekulovat o povaze a autorství této árie. ${ }^{42}$ Nicméně sám holý fakt by mohl svědčit o tom, že nedostatek př́ležitosti předvést schopnosti první koloraturní zpěvačky v této roli byl pocitován nejen v Praze a překonával se podobným způsobem.

Ve Škroupově autografu se vyskytuje pozoruhodný doklad toho, že se árie zpívala i potom, co Podhorská divadlo v únoru 1849 opustila. Ve zpěvním textu totiž Škroup perem

auf unbegreifliche und unverzeihliche Weise zusammengestrichen war), und in den Reprisen legte sie eine Arie ein, die ganz gewiss nicht von Halévy ist. Es scheint ein Mozart’sches Motiv zum Grunde zu liegen, das modern italienisch durchgeführt ist." Z. 17.: Prag (Beschluss), Allgemeine musikalische Zeitung, roč. 40, 1838, č. 39 (26. 9.), sloupec 646-647, zde 647. - Eudoxie (Isabella) ve IV. jednání žádnou árii nemá. Referent snad mínil arioso na začátku duetu č. 16 (Andantino espressivo, 3/4, F dur: „Ah! pour celui qui m’a trahie“), které však je obsaženo jen v klavírním výtahu, nikoli v tištěné partituře (viz HALÉVY, Fromental: La Juive. Opéra en 5 actes. Paroles de Mr Scribe. Musique de ... Partition piano \& chant, Henry Lemoine, [Paris] [s. a.], s. 312 nn). 39) „Das Lied, in die Ferne', von J. N. Škraup (empfindungsvoll durchcomponirt), eine als Einlage in Halevy’s ,Jüdin' componirte Arie trugen Hr. Strakaty und Mad. Podhorsky unter lautem Beifalle vor; [...]." T.: Concerte vom 26. und 27. Februar, Bohemia, roč. 15, 1842, č. 26 (1. 3.), s. [4].

40) „écrit par une main étrangère“. LEICH-GALLAND, op. cit. v pozn. 17, s. 156.

41) Viz ZENGER, Max: Geschichte der Münchener Oper, Verlag für praktische Kunstwissenschaft Dr. F. X. Weizinger \& Co., München 1923, s. 307-308; BAJGAROVÁ, Jitka: Rettigová, Jindřiška [heslo], in: LUDVOVÁ 2006, op. cit. v pozn. 2, s. 442-444, a in: Česká divadelní encyklopedie [online]. Dostupné z: http://encyklopedie.idu.cz/index.php/Rettigov\%C3\%Al,_Jind\%C5\%99i\%C5\%Alka [cit. 26. 2. 2021].

42) Tiskové zprávy po mnichovské premiéře Die Jüdin se o vložené árii nezmiňují a Isabellu berou jako malou úlohu. Srov. Feuilleton der Kunst. Theater, Münchener Conversationsblatt, roč. 5, 1844, č. 32 (20. 4.), s. 128; Feuilleton der Kunst. Theater, tamtéž, č. 33 (25. 4.), s. 132; Notizen über Kunst. Theater, Der Bayerische Landbote, roč. neuveden, 1844, č. 112 (21. 4.), s. 484; Königliches Hof- und Nationaltheater, Der Bayerische Eilbote, roč. neuveden, 1844, č. 48 (21. 4.), s. 391; Königliches Hof- und National-Theater, tamtéž, č. 49 (24. 4.), s. 402; Nichtpolitische Zeitung. München, 19. Juli [!], Neue Würzburger Zeitung, roč. neuveden, 1844, č. 112 (22. 4.), s. [4]; G-f.: Salon, Münchener Tagblatt, roč. 18, 1844, č. 113 (23. 4.), s. [531]; Salon, tamtéž, č. 114 (24. 4.), s. [535]; Theaternotizen, Münchener politische Zeitung, roč. neuveden, 1844, č. 99 (25. 4.), s. 394-395; Correspondenz-Nachrichten. Aus München, 21. April, Allgemeine Theaterzeitung, roč. 37, 1844, č. 100 (25. 4.), s. 415; Aus München, tamtéž, č. 104 (30. 4.), s. 432. - Zbytky provozovacího materiálu k Die Jüdin z Královské dvorní opery v Mnichově uložené v Bayerische Staatsbibliothek nenaznačují nic o existenci vložené árie pro Isabellu. Viz Die Jüdin. | Oper in fünf Aufzügen von Halevy. [Einbandetikett von 14, Bd. 1]; [Historisches Aufführungsmaterial der Bayerischen Staatsoper]. 
škrtl jména osob „Comthur“ a „Sara“, odpovídající cenzurní podobě Seyfrieda a Hofmanna, a nahradil je zněním "Cardinal“ a „Recha“. Po zrušení cenzury za revoluce 1848 bylo možné i v Praze uvádět opery v necenzurované podobě. Stalo se tak i s Halévyho La Juive, v níž stačilo vrátit děj ze 13. století a z neurčitého místa na církevní koncil v Kostnici v 15. století a nahradit smyšleného komtura templářského řádu původní „historickou“ postavou kardinála de Brogniho, aby se obecenstvu jasněji zjevily konflikty židovského a křestanského náboženství, předtím oslabené a zdeformované cenzurní úpravou. ${ }^{43}$ Když v představení 8. prosince 1849 vystoupila slečna Byri nikoli jako Isabella, neteř místodržícího, nýbrž Eudoxia, neteř císaře Zikmunda, zřejmě zpívala i vloženou árii. Árie zůstala v reprízách Die Jüdin k dispozici asi jako fakultativní vložka. Každopádně nepřetrvala Škroupův odchod ze Stavovského divadla na podzim roku 1857. Autograf partitury árie proto naštěstí nevzal za své s ostatním provozovacím materiálem a zachoval se ve skladatelově pozůstalosti.

František Škroup s místním autorem veršů se jistě nemohl přiřadit k Fromentalu Halévymu a Eugènu Scribovi jako rovnocenný partner. Přesto svou snahou překlenout objektivní dramaturgickou vadu opery La Juive významně a tvưrčím zpơsobem přispěl do její evropské recepce. Z tohoto hlediska představuje Škroupova árie jedinečný dosud známý počin svého druhu, který by si bezpochyby zasloužil vydání i novodobé provedení. Skladatel zároveň árií složil kompliment zpěvačce, která patřila tehdy po zcela nevídaně dlouhou dobu dvaceti sedmi let k nejlepším silám operního souboru pražského Stavovského divadla a napomáhala tu svým uměním také k úspěšnému pronikání děl francouzské velké opery.

Adresa: Milan Pospíšil, Nadace pro dějiny kultury ve střední Evropě / Association for Central European Cultural Studies, U Třešňovky 8, 18200 Praha 8, Česká republika

E-mail: pospisil.milan.phdr@seznam.cz

43) Po porážce revoluce $v$ Rakousku ještě před konečným zavedením neoabsolutismu byla opět omezena svoboda projevu v divadle nařízením ministra vnitra Alexandra Bacha z 25. listopadu 1850, kterým byl vyhlášen Divadelní řád. Konkrétně to znamenalo opětné zavedení divadelní cenzury a v prípadě Halévyho opery návrat k cenzurovanému znění. 